\title{
Transportation Business Plan
}

January 1986

U.S. Department of Energy

Office of Civilian Radioactive Waste Management

Washingfon, D.C. 20585

MASTER 


\section{DISCLAIMER}

This report was prepared as an account of work sponsored by an agency of the United States Government. Neither the United States Government nor any agency Thereof, nor any of their employees, makes any warranty, express or implied, or assumes any legal liability or responsibility for the accuracy, completeness, or usefulness of any information, apparatus, product, or process disclosed, or represents that its use would not infringe privately owned rights. Reference herein to any specific commercial product, process, or service by trade name, trademark, manufacturer, or otherwise does not necessarily constitute or imply its endorsement, recommendation, or favoring by the United States Government or any agency thereof. The views and opinions of authors expressed herein do not necessarily state or reflect those of the United States Government or any agency thereof. 


\section{DISCLAIMER}

Portions of this document may be illegible in electronic image products. Images are produced from the best available original document. 


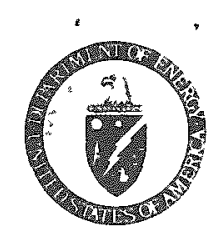

Department of Energy

Washington, D.C. 20585

Dear Reader:

The Office of Civilian Radioactive Waste Management (OCRWM) is responsible for establishing a transportation system to support shipment of spent fuel and high-level radioactive waste to repositories and storage facilities developed under the Nuclear Waste Policy Act of 1982 (NWPA). An element that assists in fulfilling that responsibility is a business plan for acquiring and operating a transportation system.

The Transportation Business Plan accompanying this letter is a step in the process of procuring the transportation system. It sets the context for business strategy decisions by providing pertinent background information, describing the legislation and policies governing transportation under the NWPA, and describing requirements of the transportation system. Included in the document are strategies for procuring shipping casks and transportation support services. In the spirit of the NWPA directive to utilize the private sector to the maximum extent possible, opportunities for business ventures are obvious throughout the system development cycle.

This plan is an outgrowth of the Transportation Business Plan Strategy options Document distributed for public comment in October 1984 and the Draft Transportation Business Plan which was distributed for public review and comment in August 1985. Comments were received from the industry and state and 1ocal governments, Indian tribes and the public at large. Careful consideration was given to each of the comments and, when appropriate, the suggestions were incorporated in this version of the plan. As can be expected, because of the complex nature of the transportation program, several comments were received which are being considered in other program documents such as the Transportation Institutional plan, and the Environmental Assessments being developed for waste management facilities. In addition, a synopsis of all the comments received and a discussion of their disposition is included in this mailing in order to advise the commentors of how OCRWM will be handiing comments not specifically germane to the Business Plan but relate to overall transportation planning strategies and plans. 
A companion document to the Transportation Business Plan is the Transportation Institutional Plan (see chapter 6), a draft of which is also now receiving public comment. That document identifies and fosters the establishment of the communication links that are vital to cooperative effort among interested parties. Both the Business and the Institutional Plans subsequently will be consolidated into the evolving Transportation plan at some future date. The transportation system acquisition task will encompass a timespan of over 12 years. Consequently, the planning for some aspects of the task is more clearly defined than for others. This will require that the planning process be an ongoing one and that this plan be updated periodically as requirements, and schedules are refined. I solicit your assistance in this process. Suggestions are welcome at any time and should be addressed to:

Mr. Robert E. Philpott

Office of Civilian Radiaactive Waste Management

U.S. Department of Energy, RW-33

Forrestal Building

1000 Independence Avenue, S.W.

Washington, DC 20585

Additional copies of this Transportation Business plan can be obtained by telephoning (202) 252-5575; by direct pick-up at the address shown below, or by writing to:

U.S. Department of Energy

Room 1E-206

Forrestal Building

1000 Independence Avenue, S.W.

Washington, DC 20585

Thank you for your interest and participation in this important activity.

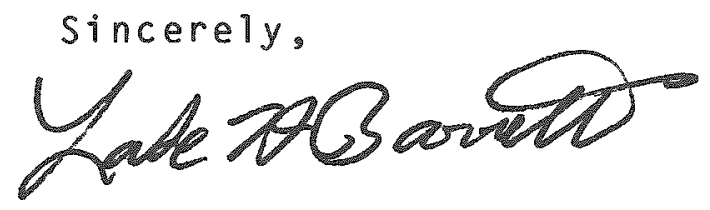

Lake H. Barrett

Director

Transportation and Waste systems Division

Office of Civilian Radioactive Waste Management 
1 EXECUTIVE SUMMARY。 . . . . . . . . . . . . . . . . . 1

2 BACKGROUND ............................. . 7

2.1 Statutory Responsibility ................. . 7

2.2 Business Plan Development ................ 7

2.3 Current Status of OCRWM Transportation Organization ...... 7

2.4 Waste Management System Description . . . . . . . . . . 7

2.4.1 The Authorized Plan .............. 9

2.4.2 The Improved-Performance Plan ............ 9

3 OBJECTIVE. ......................... 15

4 TRANSPORTATION SYSTEMS ACQUISITION PHASE I-CASK DEVELOPMENT . . . . . 17

4.1 Initiative 1 - From-Reactor Casks . . . . . . . . . . . . 17

4.1.1 Business Strategy . . . . . . . . . . . . . 17

4.1.2 Procurement/Technical Plan ............ 22

4.1 .3 Schedule .................. 23

4.2 Initiative 2 - From-MRS-to-Repository Casks . . . . . . . . 25

4.2 .1 Business Strategy ................ 25

4.2.2 Procurement/Technical Rlan ............ 25

4.2 .3 Schedule.................... 25

4.3 Initiative 3 - Nonstandard Spent Fuel and Components Casks . . . 27

4.3.1 Business Strategy . . . . . . . . . . . . . . 27

4.3.2 Procurement/Technical P1an ............. 27

4.3 .3 Schedule ................ 28

4.4 OCRWM Program Management/Control Plan ........... 28

4.4.1 Technical Management Structure ............. 28

4.4.2 Procurement Guidance ................ 31

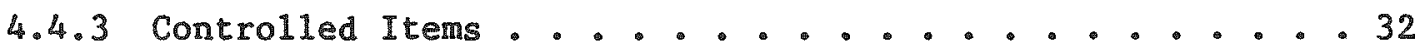

4.5 Contingent Actions .................. 33

5 TRANSPORTATION SYSTEMS ACQUISITION PHASE II--SERVICE CONTRACTORS . . . 35

5.1 Business Strategy . . . . . . . . . . . . . . . . 35

5.1.1 Service Contractors ................. 35

5.1.2 Carriage Arrangements ............ . 36

5.1.3 Training . . . . . . . . . . . . . . . 37

5.1 .4 Inspection, Maintenance, and Repair ........ 37

5.1.5 Service Contractor Interfaces with Utilities . . . . . 37

5.2 Procurement/Technical Plan .............. 38

5.2.1 Early Carrier Discussions . . . . . . . . . . . 38

5.2 .2 Preprocurement Planning ............. 38 
TABLE OF CONTENTS (Continued)

Page

5.2.3 Service Contractor Procurement . . . . . . . 38

5.2.4 Fleet Procurement . . . . . . . . . . . . . 38

5.2.5 Preoperational Preparations . . . . . . . . . . 39

5.2.6 Transportation Operations . . . . . . . . . . 39

5.3 OCRWM Program Management/Control Plan ........... 39

5.3.1 Technical Management Structure ........... 39

5.3 .2 Procurement Guidance .............. . 39

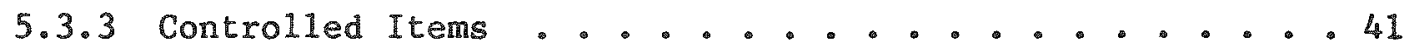

5.4 Schedule ...................... 42

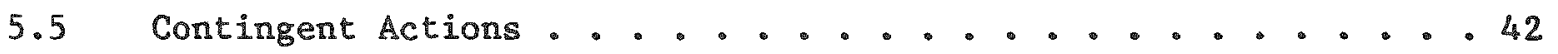

6 TRANSPORTATION INSTITUTIONAL PROGRAM ELEMENTS . . . . . . . . . 45

6.1 Transportation Institutional Plan ..............45

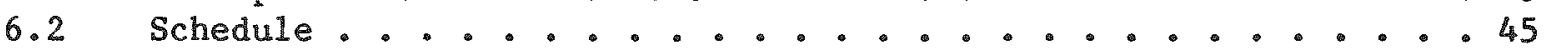

APPENDIX A Waste Acceptance Schedules . . . . . . . . . . . . 47

APPENDIX B I1lustration of the Improved-Performance System Concept . . . 51 


\title{
LIST OF FIGURES
}

1-1 Evolution of the Transportation Plan .............. $\frac{\text { Page }}{2}$

1-2 Work Breakdow Structure for the Transportation Systems

Acquisition Task ...................... 4

1-3 Transportation Program Schedule ................ . 6

2-1 OCRWI Transportation Organization Structure . . . . . . . . . . 8

2-2 The Waste-Disposal System Current1y Authorized by Congress . . . 10

2-3 Improved-Performance System With Integra1 MRS Facility . . . . . 11

2-4 Distribution of Waste Management Functions in a System

With an Integrated MRS Facility ................. 13

4-1 Transportation Systems Acquisition Phase I--Initiative 1 . . . . 24

4-2 Transportation Systems Acquisition Phase I--Initiative 2 . . . . 26

4-3 Transportation Systems Acquisition Phase I--Initiative 3 . . . . 29

4-4 Cask Development Program Management Structure . . . . . . . . . 30

5-1 Transportation Operations Program Management Structure ...... . 40

5-2 Transportation Systems Acquisition Phase II . . . . . . . . . 43

\author{
LIST OF TABLES
}

4-1 Cask Testing Summary. . . . . . . . . . . . . . . . 21 
Chapter 1

EXECUTIVE SUMMARY

The Nuclear Waste Policy Act of 1982 (the "Act ${ }^{\text {"D }}$ ) authorized the U.S. Department of Energy (DOE) to establish a national system for the disposal of spent fuel and high-level radioactive waste and established the office of Civilian Radioactive Waste Management (OCRWM) to carry out these duties. A primary element of the Civilian Radioactive Waste Management Program is the development of the transportation system required to support the waste management system. The Act also directs the DOE to "utilize by contract private industry to the fullest extent possible in each aspect of such transportation" (Section $137(\mathrm{a})(2)$ ).

Certain tasks must be achieved by the DOE in planning, designing, developing, and operating the transportation system for the civilian waste management program. These tasks, as stated in the Mission Plan For the

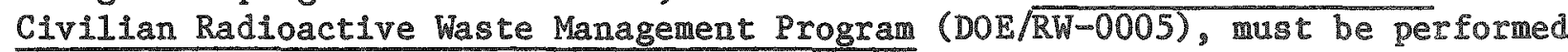
in a parallel and complementary manner. They are

1. The institutional development and the operation of the transportation system or the "Transportation Institutional Task."

2. The technical development of the transportation system or the "Transportation Systems Acquisition Task。"

The DOE is defining the strategles to address these two tasks through the development of initially separate but interrelated documents. This

Transportation Business P1an focuses on the technical development of the spent fuel and radioactive waste transportation system (Transportation Systems Acquisition Task) by presenting information on expected business opportunities, methods, and strategies. It is complemented by the Transportation Institutional Plan that was first published in draft form (DOE/RW-0031) in September 1985. This latter document defines the comprehensive process being followed by OCRWM to identify, address, and resolve the institutional issues related to waste transportation. As the transportation system develops, an operations plan detailing how the system will function will be added. Eventually, as the DOE continues its systems planning, a11 of these program element plans will be combined into a single, integrated document (Figure 1-1). The goal is to provide a comprehensive Transportation P1an offering information and guidance to a11 who w11 particlpate in and will be affected by the transportation of spent fuel and high-level radioactive waste.

The acquisition strategy developed in this plan is designed to support elther the authorized plan or the improved-performance plan as outined in the Mission P1an (DOE/RW-0005). The improved-performance plan would expand the authorized plan to include a monitored retrlevable storage (MRS) facility, if approved by Congress, that could perform some of the repository waste processing functions and provide improved control over spent fuel transportation operations between nuclear power reactors and the repository. 


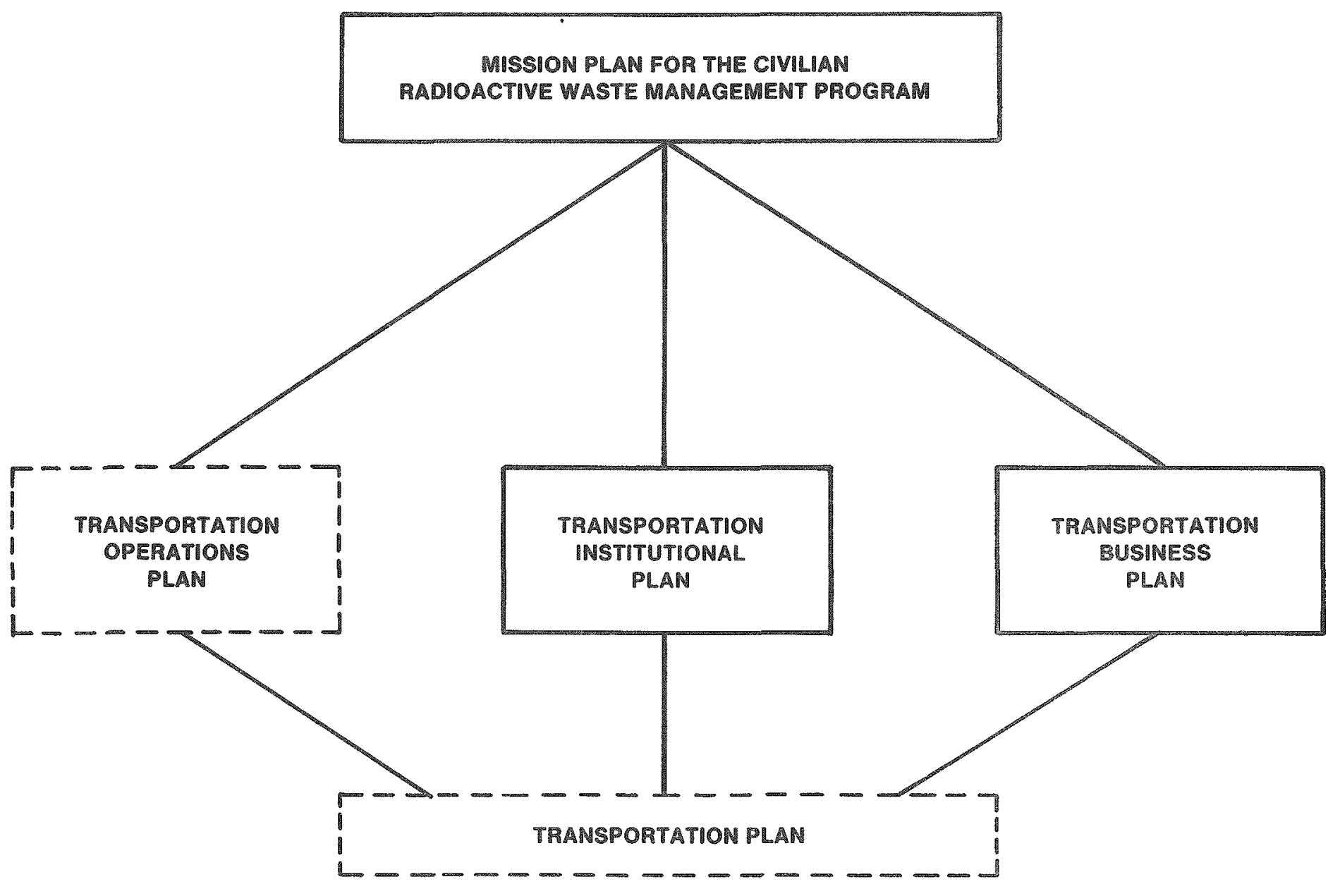

AVAILABLE DOCUMENT

PROJECTED DOCUMENT

Figure 1-1. Evolution of the Transportation Plan. 
The Transportation Systems Acquisition Task is divided into two phases as shown in Figure 1-2. Approved quality assurance plans wi11 be followed during both phases. Phase I covers the development and acquisition of prototype casks that will be used to ship civilian radioactive waste to or between Federal facilities. The DOR will develop and implement transportation operations during Phase II.

OCRWM w111 use private industry to the maximum extent possible in both of these phases. Activities to be performed by private industry during Phase I include contracting for cask development and certification and prototype fabrication of casks. As part of Phase II, OCRWM will contract with private industry to supply a transportation fleet from qualified designs established under Phase I; to provide inspection, maintenance, and repair services; to train operations and security personnel; and to manage and conduct transportation operations.

Phase I is composed of three initiatives to develop casks to be used by OCRWM. Initiative 1 covers the development of the spent fuel (intact assemblies and consolidated rods) casks that will be used to ship most of the radioactive waste from reactors. A request for proposals (RFP) w111 be 1 ssued in 1986 to private industry for supplying prototype spent fuel casks that are certified by the Nuclear Regulatory Commission (NRC). At least two designs for each primary modal option w111 be developed. OCRWM will perform or will require its contractors to perform scale model, component, and operational tests to ensure compliance with NRC performance criteria. It is desirable that al1 prospective spent fuel cask suppliers respond to the Initiative I RFP to enable OCRWM to develop a list of qualified bidders to be used in Phase II, Initiative II of the fleet procurement process. Other qualified designs could be added later, provided that they meet the following conditions when the fleet procurement proposals are submitted:

- Have an NRC certificate of compliance.

- Meet OCRWM interface and performance requirements.

- Are available within the OCRWM schedule.

- Meet the testing requirements of the NRC and the DOE.

- Provide an operational prototype cask.

Anyone desiring funding under Initiative I must respond to this RFP. Costs for this cask development initiative are estimated to be approximately $\$ 75$ million (1985 dollars). This task will be undertaken in a competitive environment to ensure that the process is cost effective.

The second initiative of Phase I will be completed if MRS is approved by Congress. This initiative will potentially provide for the development of a speciallized cask system for transporting waste between the MRS facility and the repository. For these shipments, the DOE is proposing to use a large, efficient rail cask to transport waste packages to the repository. Prototypes of these specialized casks will be competitively procured though a process similar to Initiative 1. However, the RFP for Initiative 2 wil1 be issued only if an MR facility is authorized by Congress and if the development of a specialized cask system is justified from cost and safety perspectives. The cost for this initiative is estimated to be about $\$ 30$ milion (1985 dollars).

The third and final Phase I initlative will be the development and/or procurement of specialty casks for nonstandard spent fuel and non-fuel hardware destined for repository disposal. Following detalled 


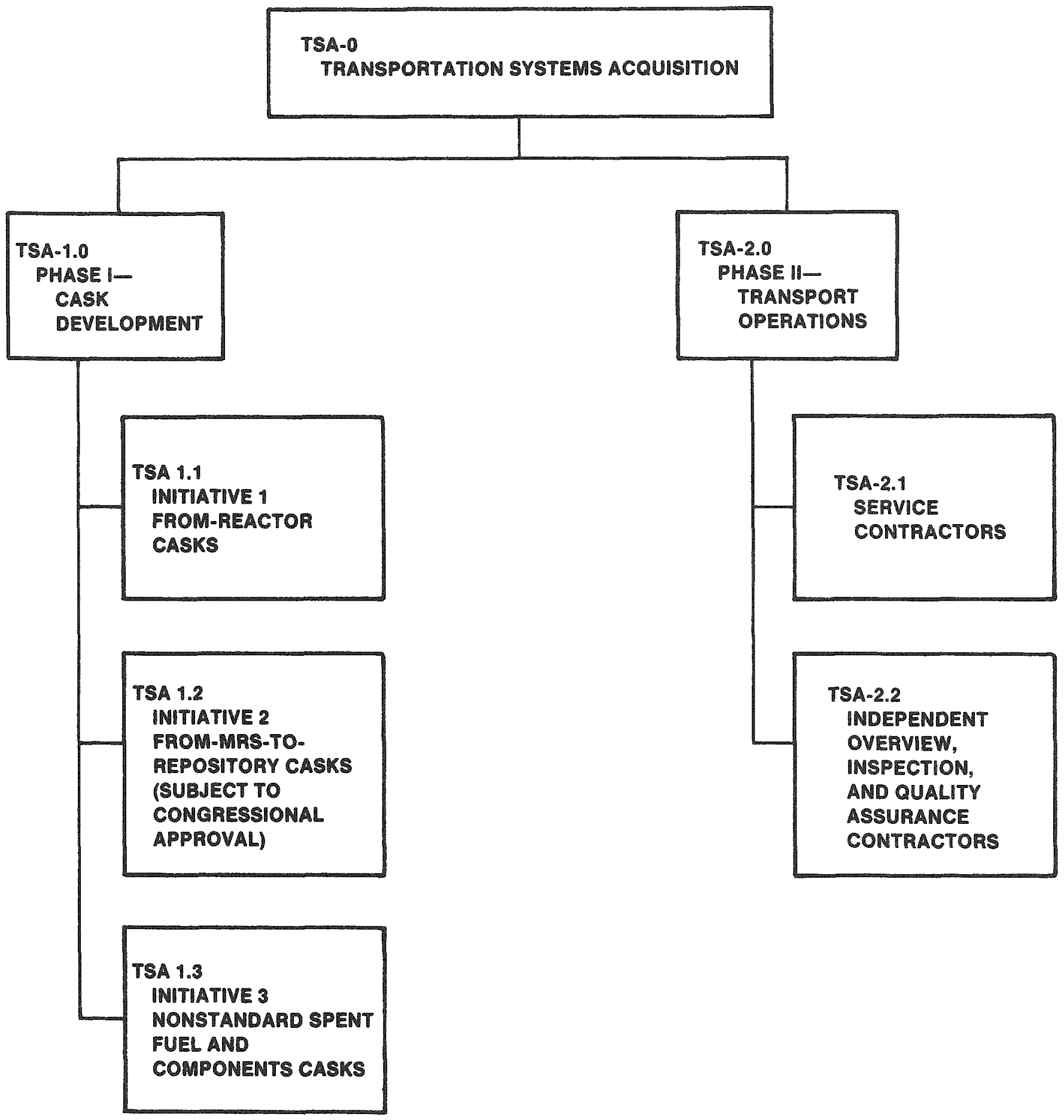

Figure 1-2. Work breakdown structure for the Transportation Systems Acquisition Task 
characterization of the materials to be shipped, a competitive RFP, if needed, wi11 be issued by the Phase II service contractor for the design and fabrication of prototype casks to be used to transport these wastes. The DOE may ultimately use several options such as assembiing a fleet of casks with valid NRC certificates of compliance; amending the NRC compliance certificates of casks developed under Initiative 1 or developed independently by the bidder; or establishing new specialty casks. Initiative 3 is expected to occur in the mid-1990s and costs should be less than \$30 million (1985 dollars).

The three initiatives in Phase I do not cover the acquisition of casks for transporting defense high-level radloactive wastes. This issue of the Transportation Business Plan addresses only waste materials that are covered by utility contributions to the Nuclear Waste Fund created by the Act. Because of significant differences in the size, weight, and source term of defense materials (e.g., defense high-level waste canisters are two-thirds the length of spent fuel assemblies), it is extremely unlikely that the casks developed for civilian spent fuel will be used for defense wastes. However, if casks developed with support of the Nuclear Waste Fund are used for defense Waste, a user fee 111 be negotiated with the office of the Assistant Secretary for Defense Programs within the DOE to recover appropriate costs. As a result of the decision to dispose of defense wastes at the repository, the DOE is now evaluating options for the transport of defense wastes. At a time well in advance of repository operation, the plans for transporting defense wastes will be publicly announced and included in future issues of this plan or the comprehensive transportation plan.

The commercial high-level waste at West Valley, New York, is expected to be very similar in form and characteristics to the defense waste that mould be shipped to a civilian waste repository. Since only small quantities of wastes from West Valley need to be transported ( 300 canisters), it is being evaluated as a special case. A decision on cask selection for transporting Vest Valley high-level waste will be reflected in the next update of the Transportation Business Plan or the first issue of the Transportation P1an.

OCRWM will develop its transportation operational program during Transportation Systems Acquisition Phase II. The operational activities include procuring of a fleet of casks, arranging carriage activities, maintaining equipment, inspecting equipment, planning and scheduling operations, and training all operating personne1. First, OCRWM WII define the most efficient and cost-effective service arrangements. OCRWM currenty expects to issue an RFP to competitively solicit private companies to serve as service contractors. All fleet-procurement actions and transportation operations by the private sector will be subjected to rigorous DoE supervision and will be required to comply with DOE, NRC, and U.S. Department of Transportation (DOT) regulations. The cost for procuring the cask fleet and developing a transportation operational capability for a 5-year period in Phase II is estimated to be over $\$ 100$ million (1985 dollars). This procurement will be conducted in a competitive, cost effective manner.

OCRIM plans to have its transportation system operational in the mid-1990s in order to service the startup of a proposed MRs facility (subject to Congressional approval) in 1996 and of a geologic repository in 1998. The summary schedule for the Transportation Systems Acquisition Task is shown in Figure 1-3. 


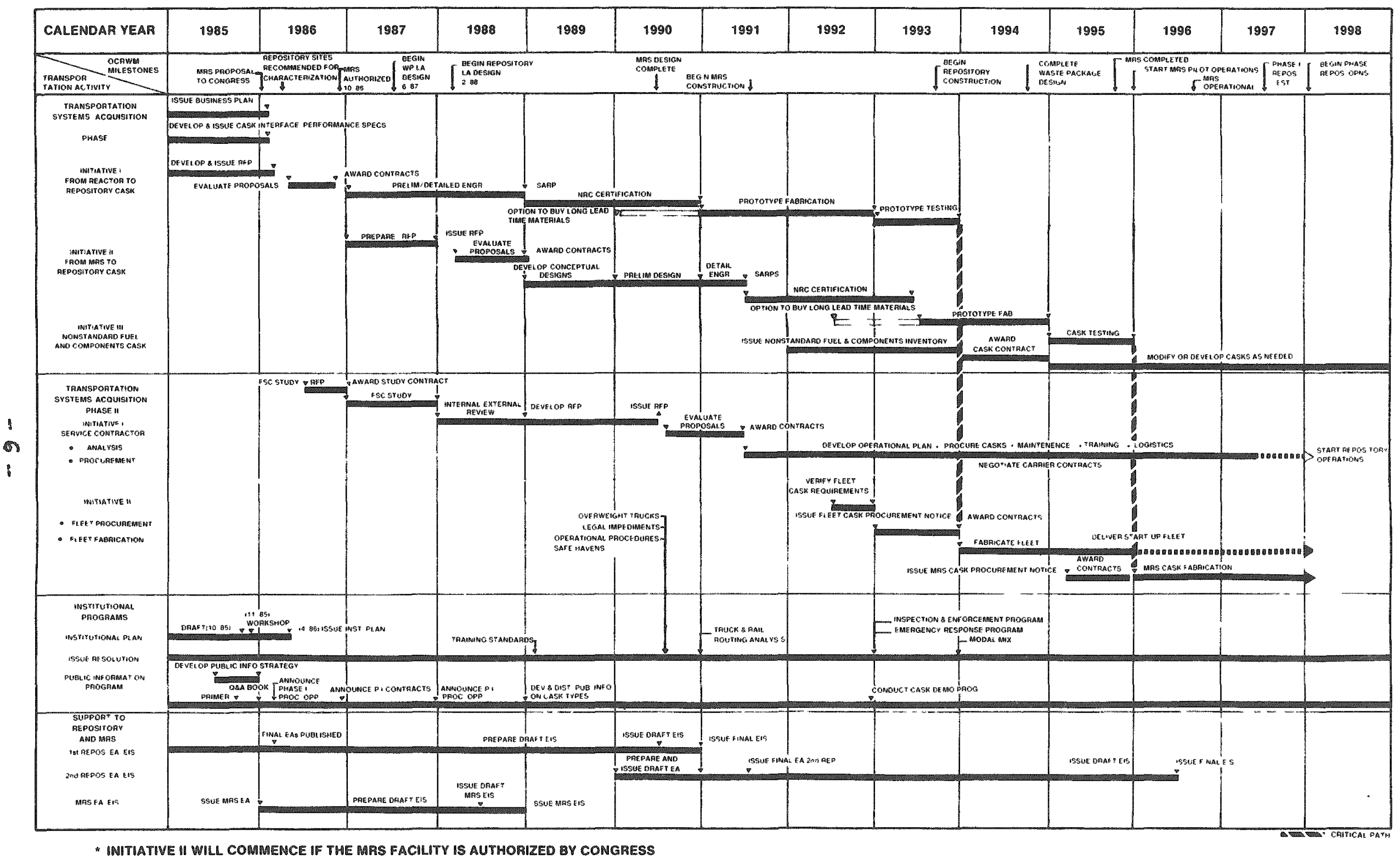

" INITIATIVE II WILL COMMEMCE IF THE MRS FACILITY IS AUTHORIZED OY CONGRESS

Figure 1-3. Transportation program schedule. 
Chapter 2

BACKGROUND

\subsection{Statutory Responsibility}

The Nuclear Waste Policy Act of 1982 created the office of Civilian Radioactive Waste Management whin the U.S. Department of Energy and assigned to it the lead responsibility for carrying out the functions provided for by the Act. One of the primary responsibilities is the transport of spent fuel and high-level radioactive waste to the facilities developed under the Act. In carrying out these responsibilities, OCRM is required by section $137(\mathrm{a})(2)$ of the Act to "utilize by contract private industry to the fullest extent possible in each aspect of such transportation."

\subsection{Business P1an Development}

The DOE has placed a high priority on the development and implementation of a Transportation Business Plan that defines the technical development of the spent fuel and radioactive waste transportation system. The first step was to develop and publish a Transportation Business P1an: Strategy Options Document (DOE/RW-0007, October 1984). Through written comments and a pub1ic workshop, the DOE received valuable input to the plan strategy from potential business participants and other interested parties. Following careful consideration of these comments, the DOE selected the specific strategies and plans that were first outlined in the Draft Transportation Business Plan (DOE/RW-0026, August 1985). During a public comment period, additional useful comments on how to improve and refine the plan were received. After consideration of these comments, this revised document was published. Although no specified schedule has been established, the DOE wi11 update this plan as required. As stated in Chapter 1 , the intended goal is to compile this and other related documents into a well-conceived, comprehensive plan for the transportation program.

\subsection{Current Status of OCRWM Transportation Organization}

A team has been established within the office of Civilian Radioactive Waste Management to plan and direct transportation projects. The transportation organization structure is show in Figure 2-1.

\subsection{Waste Management System Description}

The Mission P1an (DOE/RW-0005) strategy for meeting the requirements of the Act sets forth two waste management plans, the authorized plan and the improved-performance plan, which have a significant impact on the development, acquisition, and operation of the transportation system. These plans are described briefly below. 


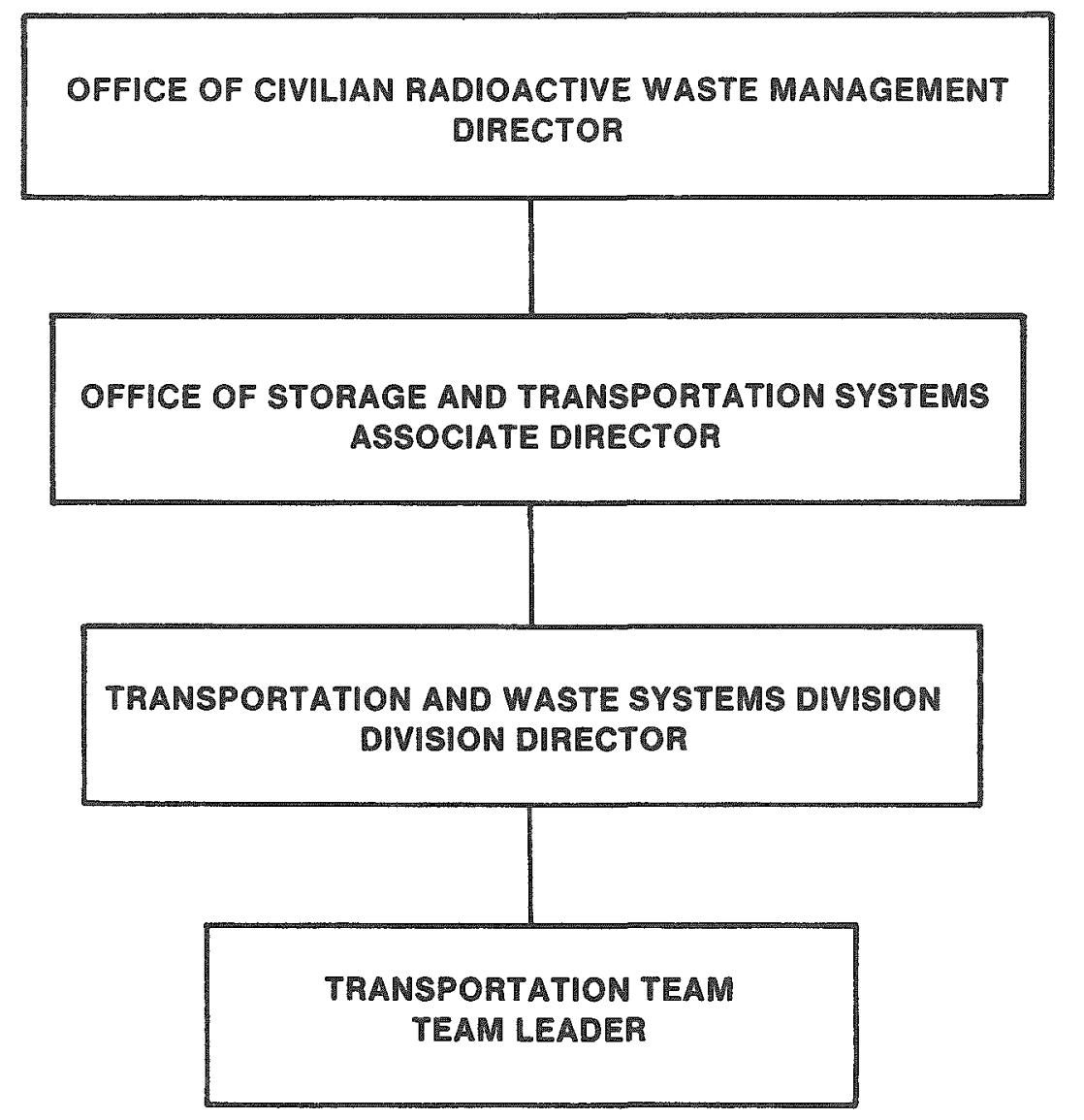

Figure 2-1. OCRWM transportation organization structure. 


\subsubsection{The Authorized Plan}

As shown in Figure 2-2, the Act authorizes a number of key activities that, taken together, can meet the objectives of providing for the permanent disposal of spent fuel and high-level waste. In particular, the Act authorizes the development and operation of a geologic repository; the recommendation of suitable candidate sites for a second repository; the necessary transportation system for moving the wastes to the repository: a provision for Federal interin storage for "civilian nuclear power reactors that cannot reasonably provide adequate storage capacity at the sites of such reactors when needed to assure the continued, orderly operation of such reactors;" and a progran to cooperate with the private sector in demonstrating the dry storage of spent fuel at reactor sites. These goals, together with other key requirements stated in the Act (e.g., the need to obtain Congressional authorization for the construction of the second repository), constitute the minimum set of activities that the program will vigorously implement.

\subsubsection{The Improved-Performance Plan}

The improved-performance plan (see Appendix B) reflects the opportunities built into the Act to evaluate options for enhancing the authorized plan in reeting the requirements of the Act. Careful analyses of the provisions of the Act and of programmatic options have shown that increased confidence and improved performance can be achieved by emphasizing systems integration--that is, by considering all of the elements of the program as part of a single system, optimized as a unit to best meet the program requirements.

This concept of optimizing the system by integrating al1 the facilities and components applies not only to the authorized plan but also to any other waste management system that could be developed to meet the requirements of the Act. In particular, the Act requires the DOE to complete a detailed study of the need for, and the feasibility of, monitored retrievable storage (MRS) and to submit a proposal to Congress for the construction of one or more MRS facilities. Analyses to date continue to reinforce the tentative conclusion that an MRS facility fully integrated into the overall waste management system as shown in Figure 2-3 can significantly enhance several important program objectives.

The studies and analyses necessary to fully describe the MRS facility and to define its potential costs and benefits are being prepared. The final results will be presented in a proposal to be submitted for Congressional consideration, as required by the Act. Should the Congress authorize the construction of an integrated MRS facility, the improved-performance plan will become the reference program plan, and the improved-performance system described in this document will be the reference waste management system.

The improved-performance plan (subject to Congressional approval of MRS), has the potential for the use of specially designed equipment for transporting spent fuel between the MS Facility and the repository. For this reason, the improved-performance plan concept has been addressed in the formulation of this Transportation Business Plan. 


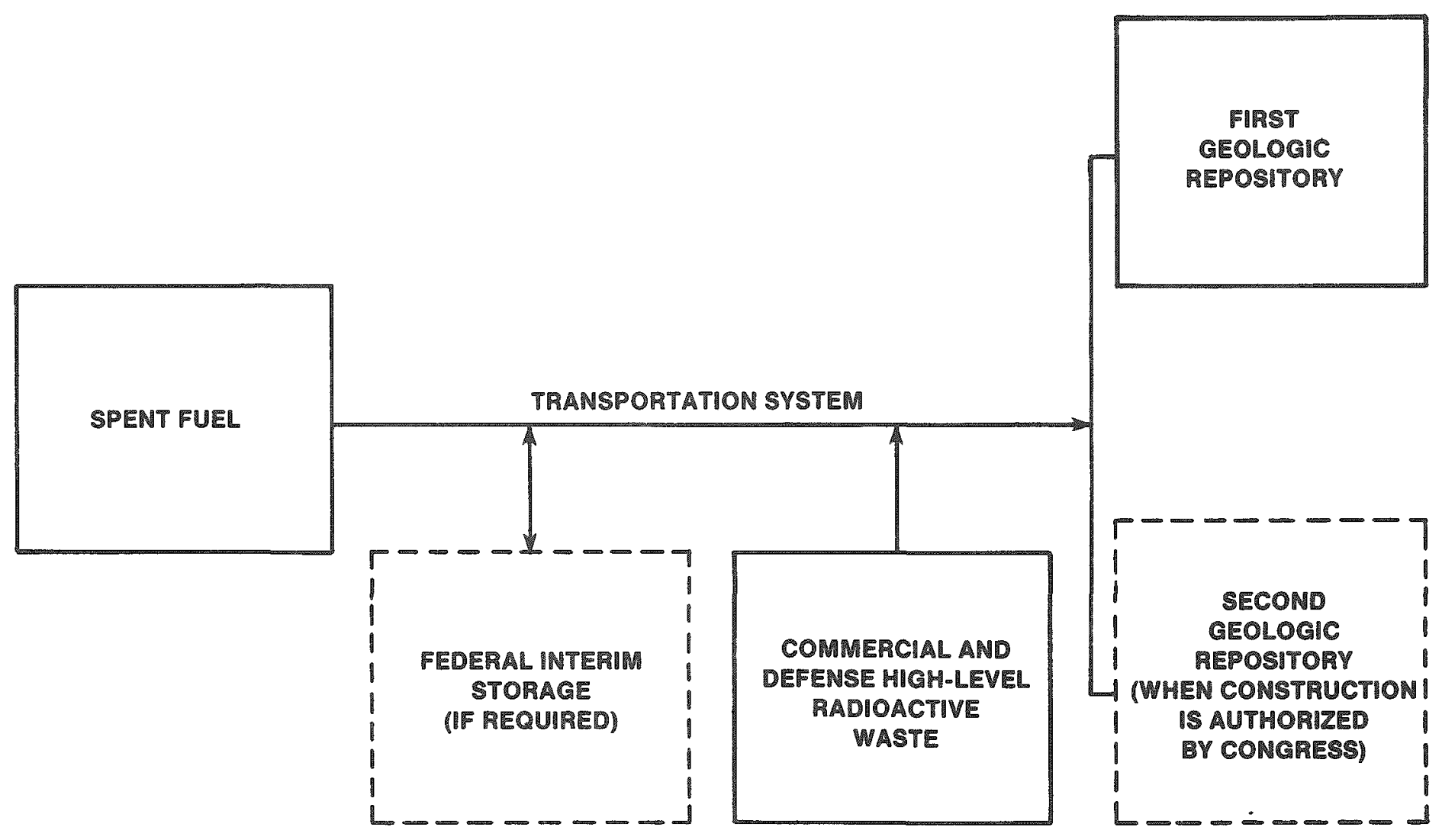

Figure 2-2. The waste disposal system currently authorized by Congress. 


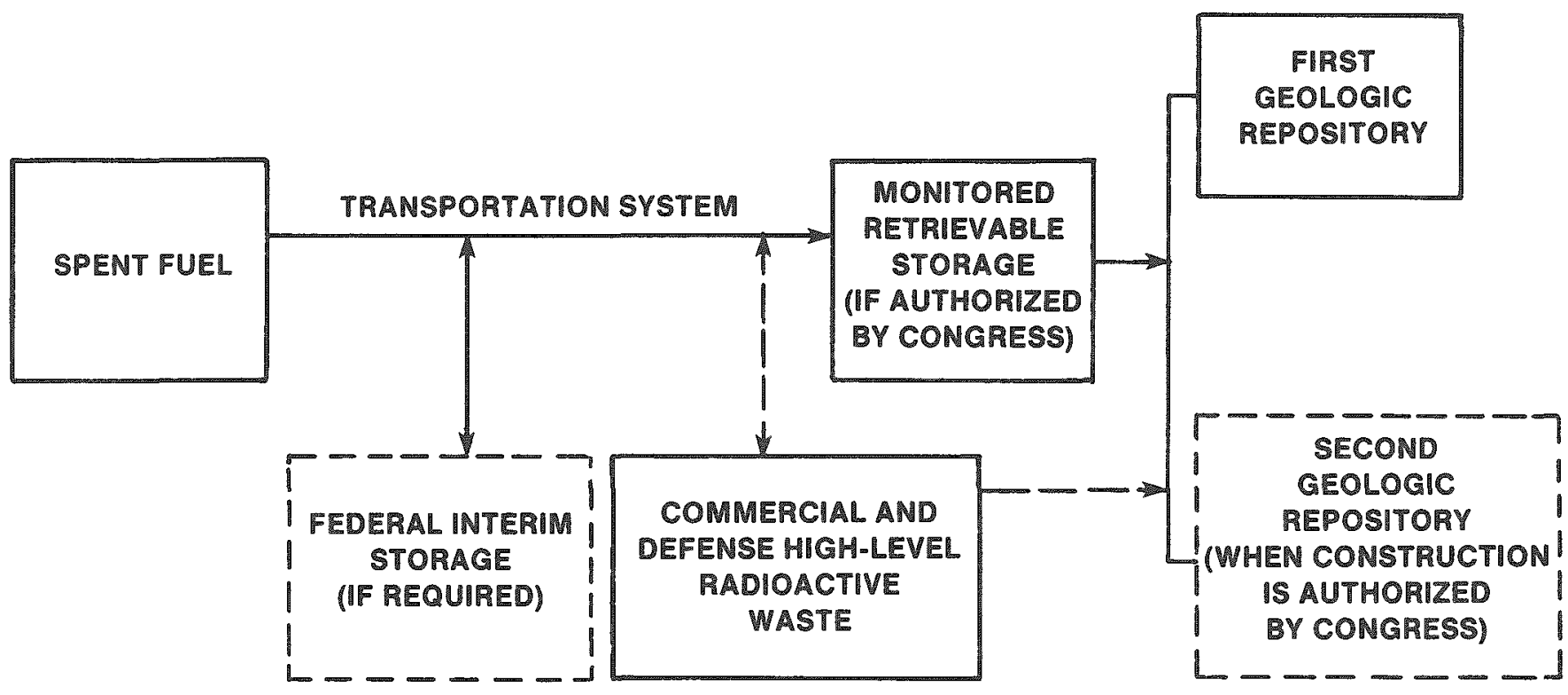

NOTES:

TRANSPORT OPTION TO BE DETERMINED

Figure 2-3. Improved-performance system with integral MRS facility. 
Spent fuel that will be accepted by the DOE for disposal may consist of various types of intact fuel assemblies or canisters of consolidated spent fuel rods from commercial reactors. If an MRS facility is authorized by Congress, spent fuel could be shipped directly from reactor sites to the MRS facility as early as 1996. Approximate projected waste acceptance schedules are shown in Appendix A. The first geologic repository is planned to begin operation by 1998. The second repository would commence operations 8 years later. Solidified high-level radioactive waste could be shipped directly to the repository from the sites where it was generated or to the proposed MRS facility, where it may be combined with other waste for shipment to the repository. Shipments will be made by rail, truck, or barge using specially designed, shielded transportation casks that comply with applicable safety regulations. The number of spent fuel shipping casks presently available is inadequate to handle the expected number of shipments. New shipping casks designed for transporting the older and cooler spent fuel to the DOE's disposal facilities would be added to the transportation component of that system. Current estimates indicate that the capacity of new shipping casks projected to be available by 1996 would be nearly twice the capacity of existing casks.

Shipping 3000 metric tons per year of spent fuel from reactors in the larger casks to a Federal facility would be accomplished using from 700 to 1400 truck shipments and 200 to 500 rail shipments. If approved, an MRS facility could be used to consolidate and package spent fuel from commercial reactors before shipment to the geologic repository for disposal. As a result of waste consolidation practices at an MRS facility, if the MRS facility were sited in the East and the repository were sited in the West, the total number of shipments in progress at any given time could be significantly reduced. In addition, the proposed MRS facility could provide 1 imited temporary storage if necessary for all waste received by the DOE and awaiting shipment to the repository. Al1 transfers will be made in such a manner as to minimize the number of shipments. Because of rail casks' projected larger capacities and the consolidation that could occur at a proposed MRS facility, there would be approximately 20 to 80 rail shipments (five to ten casks per shipment) per year to a repository.

The potential flow of waste from nuclear power plants to the DOE's disposal facilities is illustrated in Figure 2-4. 


\section{Dismbution of Wasto Managament Functions in a System With an Intograted MRS Faoilty}
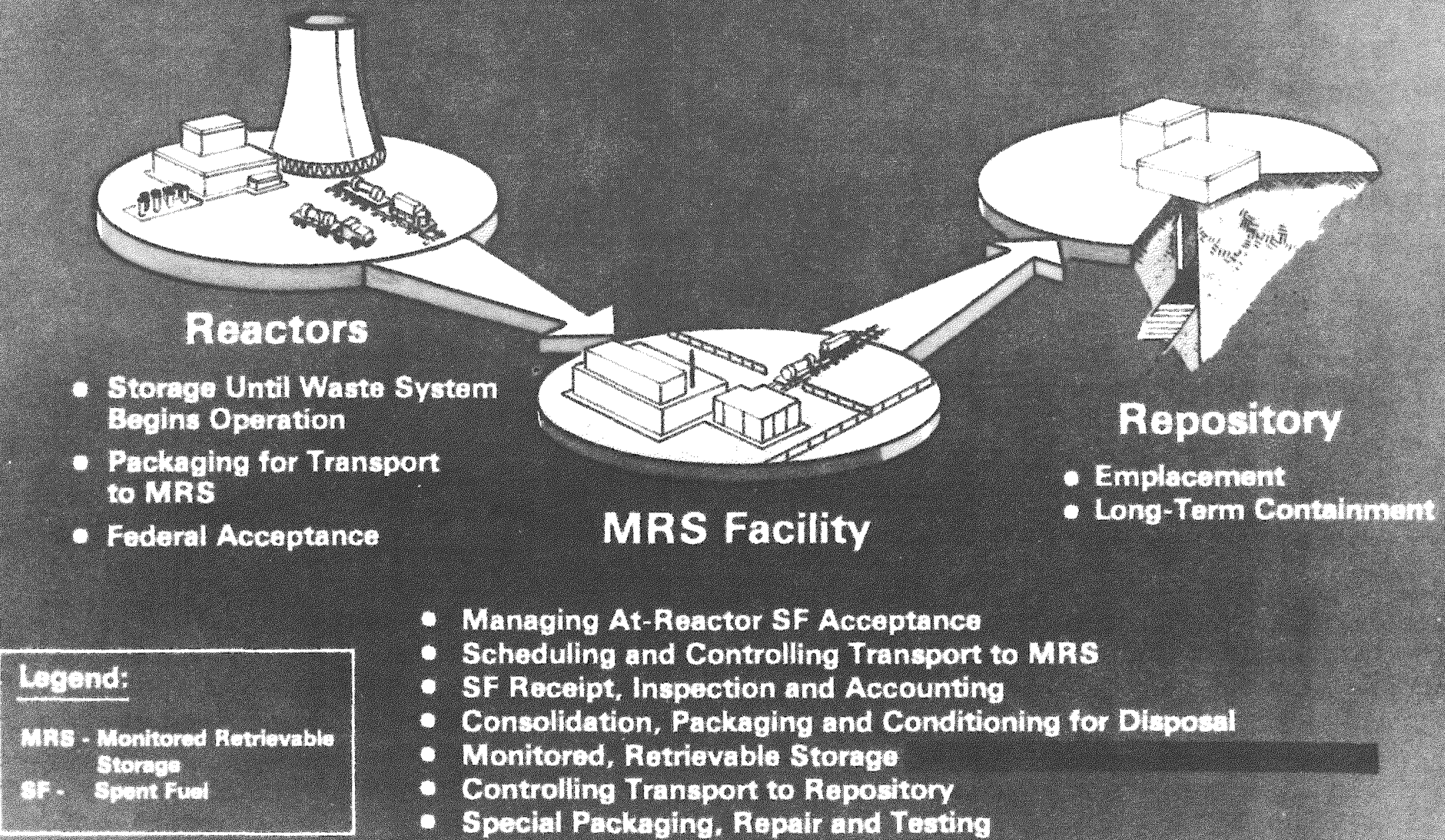

- Managing At-Reactor SF Acesptanco

- Schaduling and Controlling Transport to MHE

O SF Rocelpt Inspoction and Accounting

- Consolidation, Packaging and Condhioning for Dltopt

o Montorod, Rowiovablo storero

- Controlling Transpent ro Fopotion

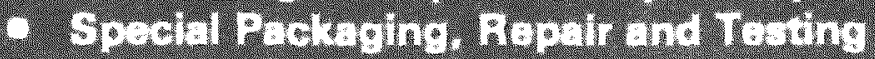




\section{THIS PAGE WAS INTENTIONALLY LEFT BLANK}


Chapter 3

\section{OBJECTIVE}

The Department of Energy's Office of Civilian Radioactive Waste Managenent will establish a safe, authorized, economical, and publicly acceptable waste transportation system in ful1 compliance with applicable regulatoxy requirements to ensure that radioactive waste managenent needs are met in a timely fashion and with maximum feasible participation by the private sector. The transportation system is the connecting element between the waste generator and the handling, packaging, and disposal elements of the operating system. In addition, the DOE's commitment to begin receiving radioactive waste for disposal in 1998 is unequivocal. Thus, supportive actions such as the development of adequate transportation capabilities will be conducted to ensure successful startup of the disposal program on schedule.

This Transportation Business Plan presents information concerning the OCRWM's expected business opportunities, methods, and strategies for establishing the transportation system to carry out this mission. Specific DOE objectives are as follows:

- To ensure the availability of transportation equipment needed to complete the required shipments from waste generators. This equipment will maximize payload in order to reduce the number of shipments while fully complying with all applicable safety requirements.

- To establish a transportation system to safely conduct shipments in a timely fashion.

- To acquire specialized transportation equipment if needed.

- To maintain and enhance institutional relationships needed to establish the transportation systern and to conduct transportation operations in a publicly acceptable manner that is in full compliance with applicable regulations.

The DOE intends to continue to utilize the capabilities of private industry to provide equipment and services for transporting radioactive waste. At the same time, the DOE must actively oversee the transportation system in order to ensure that a safe, viable transportation system is ready on time. The DOE's transportation needs result in two potential business phases for private industry. The term "private industry" refers to the cask-equipment and service suppliers. Utilities have a unique position in the program as the generators of the waste materials being transported. While a portion of their role is contractually defined in signed versions of the Standard Contract for Disposal of Spent Nuclear Fuel and/or High-Level Radioactive Waste (10 CFR Part 961), additional aspects of their role are defined separately in this plan, where applicable.

The first transportation systems acquisition phase covers three cask development initiatives. The first initiative is the development and prototype fabrication of a family of truck and rail/barge casks needed to 
transport spent fuel (either as intact assemblies or as consolidated rods) from the reactors. Also included in this initiative is the development of storage/transport casks. Such prototypes must be proven in enough time to procure a fleet that will accommodate the first shipments to the proposed MRS facility scheduled to begin as early as January 1996.

The second cask development initiative of Phase I will be to develop competitive prototype cask systems for transporting wastes between an MRS facility and a repository if Congress authorizes MRS. These casks will be designed to accommodate consolidated fuel in repository packages and to meet high payload requirements, which will be better defined over the next several years.

A third cask development initiative will be to procure specialty casks for nonstandard spent fuel or non-fuel materials, such as nonstandard spent fuel, burnable poison rod assemblies, fuel assembly hardware from spent fuel consolidation operations, control rod elements, thimble plugs, fission chambers, and neutron sources, that may be destined for the repository. If these materials cannot be efficiently transported in the casks developed under the aforementioned initiatives or in NRC-certified casks developed independently by private companies, the DOE will acquire at least two new specialty cask designs to accommodate such shipments.

It should again be noted that the above initiatives do not include the procurement of casks for defense high-level wastes.

During the second major transportation systerns acquisition phase, the DOE will thoroughly evaluate the use of service contractors for proposed transportation operations. If this option is shown to be efficient and cost-effective, the DOE will competitively select one or more service contractors. Those service contractors will be responsible for (1) procuring a transportation fleet from qualified designs established under Phase I, (2) making carriage arrangements, (3) providing inspection, maintenance, and repair services, (4) training operations and security personnel, and (5) managing transportation operations. 
Chapter 4

TRANSPORTATION SYSTEMS ACQUISITION PEASE I--CASK DEVELOPMENT

Transportation Systems Acquisition Phase I includes the development of prototypical spent fuel and radioactive waste casks required by the Dor for civilian radioactive waste transport. Three initiatives will allow the DOE to ensure the availability of certified casks for the following uses: (1) shipments of spent fuel and consolidated fuel rods from most reactors to facilities in the Federal disposal system; (2) shipments of spent fuel (potentially in ready-for-emplacement repository packages) between an MRS facility and a repository in an integrated disposal system; and (3) shipment of nonstandard spent fuel and non-fuel materials (where applicable) from reactors or other facilities to Federal disposal facilities. These cask initiatives are respectively referred to as (1) From-Reactor Casks, (2) From-MRS-to-Repository Casks, and (3) Nonstandard Spent Fuel and Components Casks. The term "cask" in this chapter includes not only the packaging or cask but also the tie-downs, vehicular conveyance, and associated ancillary equipment. Adherence to approved quality assurance (QA) procedures is required for all cask development activities. OCRWM is currently developing a transportation QA plan based on NRC QA requirements.

\subsection{Initiative 1 - From-Reactor Casks}

The DOE plans to ensure that equipment for transporting radioactive waste will be available to make shipments beginning in 1996. First, the DOE will establish general performance specifications for the system. Then, the DOE will issue a request for proposals (RFP) to private industry for development of a new generation of casks. At least two casks of each primary modal type (highway and rail) will be selected for engineering development and certification. Al1 commercial radioactive waste cask designs must be certified by the Nuclear Regulatory Commission (NRC) before their use in the disposal program. Prototypes will be fabricated and tested as necessary. New casks will be designed to maximize payload and to minimize life-cycle costs while fully complying with all safety-related requirements. Where appropriate, the DOE will provide technical and testing assistance to industry.

\subsubsection{Business Strategy}

The DOE will issue a request for proposals (RFP) to private industry to develop and produce prototype transportation equipment for spent fue1. This section presents OCRWM's strategy for spent fuel cask development.

\section{Scope}

The Initiative 1 RFP covers cask design and engineering (trailer and railcar designs are included), certification and testing, and prototype fabrication and will be issued in early 1986. Proposals pertinent to casks for all surface transportation modes (truck, rail, and rail/barge) will be solicited, and a matrix of packaging and modal capabilities to include storage/transport casks will be selected for development. 
The contracts awarded will be cost reimbursement contracts or no-cost contractual agreements. A proposer may choose to have OCRWM fund all cask design, certification, and prototype fabrication activities, or the proposer may seek funding for on1y certified prototype cask units. The DOE must ensure the availability of casks in the mid-1990s in order to service the start-up of the disposal facilities.

Because of the high level of public interest in the transportation of radioactive materials, the development and testing of casks to be used in the fleet must be accomplished in a publicly visible manner. DOE-supported work will be available for public review and will allow for engineering and design verification tests, open design reviews, and public inspections of prototype casks. Privately developed casks must clearly demonstrate comparable public involvement in the development and testing stages in order to be eligible for inclusion in the operational fleet. It is desirable, therefore, that all prospective spent fuel cask suppliers respond to the Initiative I REP to enable OCRWM to develop a list of qualified bidders to be used in Phase II, Initiative II of the fleet procurement process. other qualified designs could be added later, provided that they meet the following conditions when the fleet procurement proposals are submitted:

- Have an NRC certificate of compliance.

- Meet oCRWM interface and performance requirements.

- Are available within the OCRMM schedule.

- Meet the testing requirements of the NRC and the DOE.

- Provide an operational prototype cask.

Anyone desiring funding under Initiative I must respond to this RFP.

Schedule

OCRWM wi11 support the development of casks on a schedule that will allow the availability of NRC-certified prototypes by the early 1990s. This strategy is pursued for three major reasons. First, it will ensure that the transportation system is ready for disposal-system startup and operations. Second, it will allow time for acquainting the public with the equipment. Third, it will allow for an operational evaluation of the cask designs that will constitute the actual cask fleet and for development of operational procedures.

\section{Cask Design}

OCRWM plans to support development of new cask designs to meet the needs of the program. The casks will be designed by several suppliers in order to diversify sources. Also, creating a variety of designs will reduce the potential for adverse impacts that may result from the removal of any single design from service. Casks for each primary mode of surface transportation will be developed in order to establish a complete matrix of acceptable options. OCRWM encourages development of highly efficient cask designs that can reduce the number of shipments. Cask designs that will enable utilities to procure approved transportation casks for short-term at-reactor storage that can later be transferred to the cask fleet are also being considered. 
Transporting wastes from reactor sites to receiving facilities will be accomplished using casks that are certified by the NRC for transport of appropriate materials and that can be physically handled at the interfacing facilities at the time of shipment. OCRWM is encouraging the development of new cask designs in order to enhance total system safety and efficiency and to ensure the availability of casks that are designed, built, and certified according to current regulations and proper interface requirements. These designs will be based on experience gained from the use of existing casks and could include concepts that are currently under development by private industry. Two major benefits expected from developing new cask designs are increases in payload and standardization of cask interfaces. The former benefit is possible because spent fuel shipped under the waste managenent program will be cooler than that for which current casks were designed. This may reduce the cost of transportation for the entire waste management system by reducing the number of trips required. Also, the standardization of cask interfaces (which does not necessarily imply the development of standard casks) will allow for greater handing efficiency at shipping and receiving facilities and simplification of procedures for a variety of organizations that are likely to interact with these casks. The benefit of interface standardization will greatly help the DOE in meeting as-low-as-reasonablyachievable (ALARA) radiation exposure levels at receiving and handling facilities.

In order to establish consistent interface criteria, OCRWM will include performance specifications and interface guidelines with the Initiative 1 RFP. Before being finalized, these specifications will be made available to interested parties for comment. It should be noted that the interface guidelines will define cask parameters that will enable the cask to be used at all receiving locations and at most reactor sites. If accommodating a specific interface requirement of only a few reactor sites (e.g., longer fuel assemblies) renders a cask less efficient for most reactors ( $>80 \%)$, then special designs that have lower payload or use other modal options will be needed.

\section{Cask Certification}

Spent fuel casks developed under all Phase I initiatives will be certified by the NRC. The cask designer will be responsible for obtaining a valid certificate of compliance from the NRC for each type of cask being developed before the cask is finally accepted by OCRWM. Broad technical issues that arise during the design and certification process may be addressed by the DOE under its procedural agreement with the NRC and through applied technology tasks sponsored by OCRWM. The contracting officer will include "start and stop" work clauses at key points in the cask development effort. If the contractor is unable to obtain an NRC certification of the design within 2 years after the submission of a safety analysis report for packaging (SARP), the contract will automatically expire and can only be reinstated with written approval by the DOE Contracting officer.

\section{Cask Prototype Fabrication}

One or more prototypes will be fabricated for each cask developed. However, the DOE reserves the right to fabricate only those prototypes that are needed for full-scale transportation operational testing evaluations. 


\section{Cask Testing}

The DOE defines testing as those activities that verify engineering analyses and design safety, expedite the certification process, and assist the public in understanding and evaluating cask performance. It is an important aspect of the cask development program. Engineering testing, design verification testing, acceptance testing, and operational testing will be included in the development program. These tests are summarized in Table 4-1. Engineering tests will be required on all cask designs to provide data to characterize material performance or performance of cask components. Design verification testing of full-scale component sections or of scale models that are at least one quarter of actual size will be performed to demonstrate design safety and to aid in certification. Design verification testing will be used to evaluate cask performance relative to NRC design criteria. After each cask is fabricated, a set of acceptance tests, which are described in each cask's safety analysis report, must be performed before shipments can be made in the cask. Acceptance testing includes postfabrication inspections and nondestructive performance evaluations (e.g., measurement of shielding effectiveness). After passing the acceptance tests, operational tests will be conducted; these tests include handing the cask at a variety of facilities, monitoring cask system performance during transit, and transferring the cask between transportation modes.

In addition, a currently unspecified fraction of the prototype casks may be subjected to a full-scale regulatory test and/or confirmatory demonstrations. The detailed scenarios for the demonstration tests will be established through processes developed in the Transportation Institutional Plan if they are deemed to be necessary.

The DOE will either perform or require its contractors to perform any and/or all tests necessary. The DOE will assist its cask development contractors, when requested, by conducting engineering and design verification tests at national laboratories. Acceptance tests will be the responsibility of the cask development contractor. Operational tests will be performed by service contractors (see Phase II) using casir development contractors as consultants. Confirmatory tests, if performed, will be conducted by the national laboratories. All testing results will be used to determine which of the prototype designs are qualified to become fleet casks.

\section{Dua1-Purpose Casks}

The DOE recognizes that certain utilities are developing dual-purpose (storage/transport) casks for onsite storage of radioactive waste and for subsequent transfer of waste to Federal facilities from the reactors. In order to be qualified for consideration as fleet casks they must, at the time of shipment, be NRC-certified and meet transportation regulations established by the DOT and the NRC as well as meet or be adaptable to design interface requirements and satisfactorily complete an equivalent test program. Service contractors (SCs), if and when selected, will be directed by OCRWM to consider using NRC-certified dual-purpose casks, consistent with fleet requirements, that utilities may procure for storage purposes prior to the beginning of permanent disposal activities. Detailed financial arrangements are not yet defined, but the DOE procurement guide for the service contractors will take 
Table 4-1. Cask Testing Summary

\begin{tabular}{|c|c|c|c|c|c|}
\hline Type & $\begin{array}{l}\text { Responsible } \\
\text { Organizations }\end{array}$ & Tests & Mardware & $\begin{array}{l}\text { Relative Point } \\
\text { in Schedule }\end{array}$ & Location \\
\hline $\begin{array}{l}\text { Engineering } \\
\text { Testing }\end{array}$ & $\begin{array}{l}\text { Cask Development } \\
\text { Contractor }\end{array}$ & $\begin{array}{l}\text { Materials and Cask } \\
\text { components as determined } \\
\text { by contractor according } \\
\text { to plan approved by DoE }\end{array}$ & $\begin{array}{l}\text { Material specimens } \\
\text { and cask components }\end{array}$ & $\begin{array}{l}\text { Through } \\
\text { Final Design }\end{array}$ & $\begin{array}{l}\text { Any shop or lab meeting } \\
\mathrm{QA} \text { and test requirements }\end{array}$ \\
\hline $\begin{array}{l}\text { Design } \\
\text { verification }\end{array}$ & $\begin{array}{l}\text { Cask Development } \\
\text { Contractor }\end{array}$ & $\begin{array}{l}\text { Structural tests on } \\
\text { models and thermal } \\
\text { tests on component } \\
\text { sections as deter- } \\
\text { mined by contractor } \\
\text { according to plan } \\
\text { approved by DoE }\end{array}$ & $\begin{array}{l}\text { Scale-models } \\
\text { and components }\end{array}$ & $\begin{array}{l}\text { Upon completion } \\
\text { of preliminary } \\
\text { design }\end{array}$ & $\begin{array}{l}\text { DoE-approved independent } \\
\text { test facility }\end{array}$ \\
\hline $\begin{array}{l}\text { Acceptance } \\
\text { Testing }\end{array}$ & $\begin{array}{l}\text { Cask Development } \\
\text { Contractor }\end{array}$ & $\begin{array}{l}\text { Postfabrication } \\
\text { inspections and } \\
\text { nondestructive } \\
\text { acceptance tests as } \\
\text { specified by contractor } \\
\text { in Chapter } 8 \text { of Safety } \\
\text { Analysis Report }\end{array}$ & $\begin{array}{l}\text { Prototype } \\
\text { Cask }\end{array}$ & $\begin{array}{l}\text { After prototype } \\
\text { fabrication }\end{array}$ & $\begin{array}{l}\text { DOE-approved test } \\
\text { facility }\end{array}$ \\
\hline $\begin{array}{l}\text { Operational } \\
\text { Testing }\end{array}$ & $\begin{array}{l}\text { DoE/utilities } \\
\text { (Using Cask } \\
\text { Development } \\
\text { Contractor } \\
\text { Consultants) }\end{array}$ & $\begin{array}{l}\text { Facility interface and } \\
\text { handing, transport } \\
\text { operations, and } \\
\text { intermodal } \\
\text { transfer tests }\end{array}$ & $\begin{array}{l}\text { Prototype } \\
\text { Cask }\end{array}$ & $\begin{array}{l}\text { After prototype } \\
\text { fabrication. } \\
\text { prior to fleet } \\
\text { unit procurement }\end{array}$ & $\begin{array}{l}\text { Reactor, MRS facility, } \\
\text { or repository sites }\end{array}$ \\
\hline $\begin{array}{l}\text { Confirmatory } \\
\text { Demonstrations }\end{array}$ & DOE & $\begin{array}{l}\text { Scenarios and test } \\
\text { environments to be } \\
\text { defined }\end{array}$ & $\begin{array}{l}\text { Prototype } \\
\text { Cask }\end{array}$ & $\begin{array}{l}\text { To be } \\
\text { determined }\end{array}$ & $\begin{array}{l}\text { To be } \\
\text { determined }\end{array}$ \\
\hline
\end{tabular}


into account fleet requirements and the depreciated value of the cask and will be adjusted for (1) its efficiency relative to an optimal cask and (2) its remaining years of service.

\section{Existing Casks}

The DOE will consider the use of existing casks (first certified prior to 1986) that already have valid certificates of compliance if the need arises at the time the DOE receives spent fuel under the Act. Existing casks may be used for spent fuel shipments as well as for special shipments where unique reactor facility or fuel characteristic requirements exist.

\subsubsection{Procurement/Technical Plan}

Initiative 1, From-Reactor Cask Development, is divided into six work elements: preprocurement planning, procurement, design, certification, prototype fabrication, and testing. Actions within each of these work elements are reviewed in the following sections.

\section{Preprocurement Planning}

All actions needed to issue a cask development RFP will be completed. These activities include developing a statement of work: establishing initial performance specifications and interface guidelines that provide the design guidance and goals for the casks to be developed and that establish the degree of standardization required to achieve system efficiency and still allow flexibility to innovative designers; and announcing the intended issuance of the RFP in the Commerce Business Daily and the Federal Register. The RFP includes the statement of work, the technical instructions for bidders, and the evaluation criteria, as well as a sample contract. The interface guidelines and performance specifications will be an appendix to the statenent of work.

\section{Procurement}

The From-Reactor Cask Development RFP will be issued by Idaho Operations office to all organizations responding to the Commerce Business Daily and Federal Register announcements. Responsive proposals will be evaluated according to transport mode category. It is expected that multiple awards will be made and that at least two casks will be developed in each primary modal category in addition to dual-purpose (storage/transport) casks. While no formal contractor qualification determinations will be conducted prior to proposal submission, only qualified and experienced contractors will be chosen. Innovative designs will be selected if they can be shown to provide a potential for significant payback in reduced costs, enhanced safety, or increased payloads in full compliance with applicable safety requirements over the life cycle of fleet operations. After final selection of designs, contracts will be negotiated and awarded. 


\section{Engineering Design}

Preliminary designs of casks will be completed by contractors. During the preliminary design period, final performance specifications and interface guidelines will be refined and standardized interfaces established. These activities will be followed by detailed engineering of the cask designs. Scale-model or component development tests will be conducted. Technical issues that may present significant safety and cost paybacks may be addressed by the DOE through applied technology development tasks. Engineering designs approved by the DOE will be submitted by the cask development contractor to the NRC for certification.

\section{Certification}

The responsibility for obtaining a certificate of compliance from the NRC for a given cask design will rest with the contractor developing the design. Each design for a new cask used to transport civilian radioactive waste must be certified by the NRC prior to use. The DOE will consult with regulatory agencies during cask development and will sponsor actions to resolve critical technical issues that may need interpretation.

\section{Prototype Fabrication}

Prior to completion of certification, the DOE may exercise its option to authorize contractors to order long-lead-time components or materials for some designs. Upon issuance of an NRC certificate of compliance, the DOE may exercise its option to fabricate prototypes of the designs expected to be included in the cask fleet.

\section{Government Acceptance and Testing}

Upon acceptance by the DOE, a prototype cask will be subjected to an operational test and evaluation sequence. This testing will include verification of operational capabilities and safety features. Confirmatory demonstrations may be conducted on some full-scale prototypes depending on the outcome of institutional activities.

\subsubsection{Schedule}

Since multiple awards are expected under the Initiative 1 RFP, the actual schedules negotiated with each contractor will be different. A typical schedule is shown in Figure 4-1. The following activities are major milestones in this typical schedule:

- Issue cask development RFP

- Approximate starting date of Eirst contract

- Complete preliminary designs

- Accept detailed engineering designs of casks

- Cask designs certified by NRC

- Accept prototypes

- Complete prototype testing
Ear1y 1986

Late 1986

1987

1988

1990 (estimated)

1992

1993 


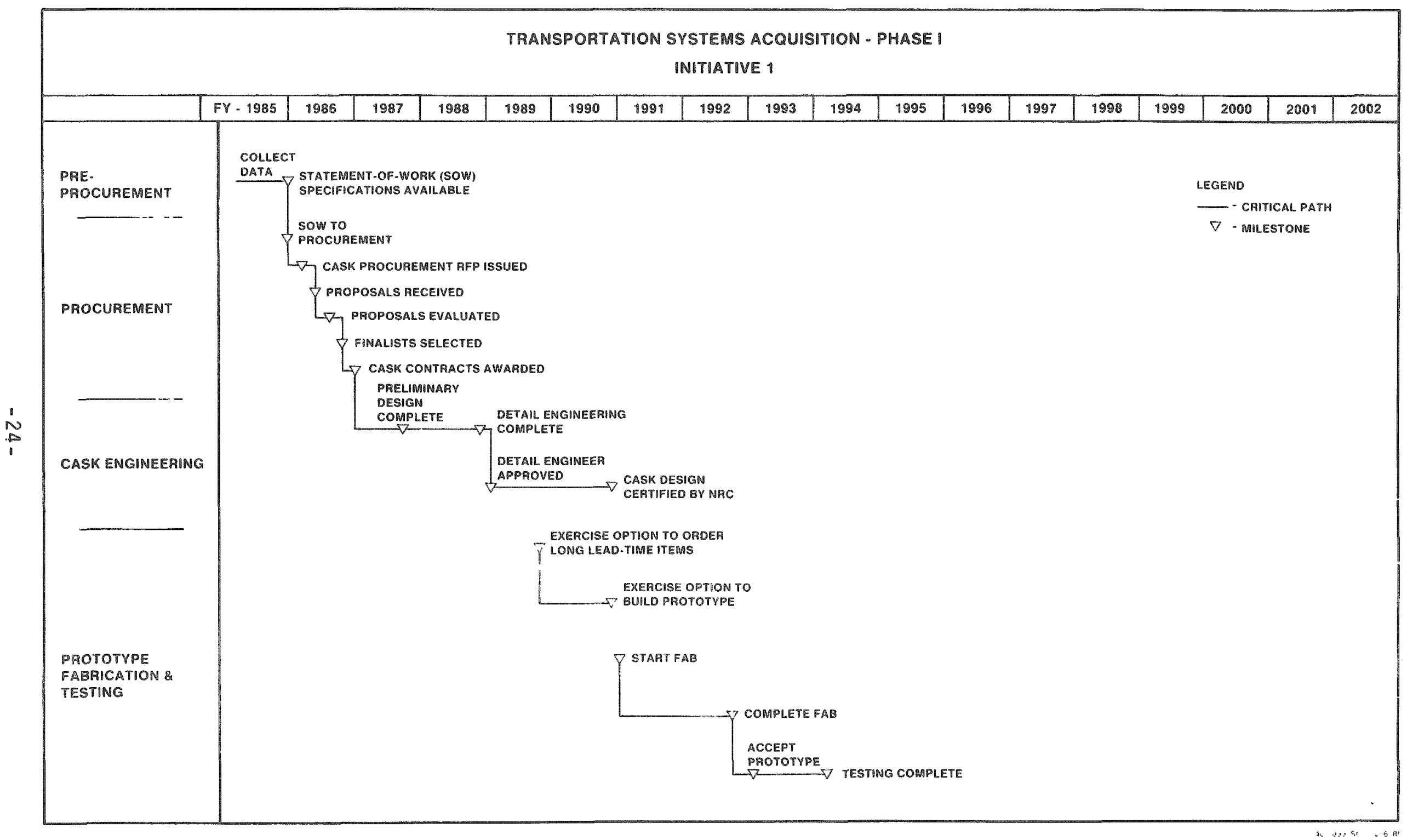

Figure 4-1. From-reactor cask development schedule. 


\subsection{Initiative 2 - From-MRS-to-Repository Casks}

If Congress authorizes an integrated MRS facility and it has been shown that a new type of cask would enhance efficiency, a specialized cask system for transporting waste from this facility to a repository will be developed.

\subsubsection{Business strategy}

The second cask development initiative that may be completed by the DOE is planning for potential shipments between the MRS facility and the repository in an integrated disposal system. For these shipments, the DOE may use either existing or new casks, but a new cask system specially designed and optimized for shipping consolidated packaged fuel from the MRS facility to the repository is considered to be more beneficial. As currently envisioned, spent fuel would be consolidated and placed in appropriate packages at the proposed MRS facility. The configuration of the waste form leaving the facility would be significantly different from that which was received. Both the repository and the MRS facility designs will be coordinated with the transportation designs to ensure the capability to handle large casks safely and efficient $1 \mathrm{y}$. The DOE is projecting a high rate of usage of rail shipments from the MRS facility if MRS is authorized.

Casks developed for Initiative 2 will be acquired under a procurement process that is similar in approach to Initiative 1. However, an RFP would be issued only if the proposed MRS facility is approved by Congress. Since a repository package probably will not be defined adequately before the late 1980 s or early $1990 \mathrm{~s}$, the final procurement actions for this cask will be delayed until the size and characteristics of the payload are sufficiently estab1ished.

\subsubsection{Procurement/Technical Plan}

Initiative 2 is divided into six work elements: preprocurement planning, procurement, design, certification, prototype fabrication, and testing. These tasks are similar in content but different in schedule from the tasks described in the technical plan for Initiative 1. A major addition is a step in the preprocurement work element to evaluate the cost benefits of developing a new, specialized cask system for shipments between Federal facilities.

\subsubsection{Schedule}

The estimated schedule for Initiative 2 is shown in Figure $4-2$. The following are major milestones in this schedule:

- Issue cask development RPP

Award contract

Accept engineering designs

Cask designs certified by NRC

Complete fabrication of prototypes

Complete prototype testing
1 year after

Congressional authorization

by 1989

by 1991

by 1993 (estimated)

by 1995

1996 


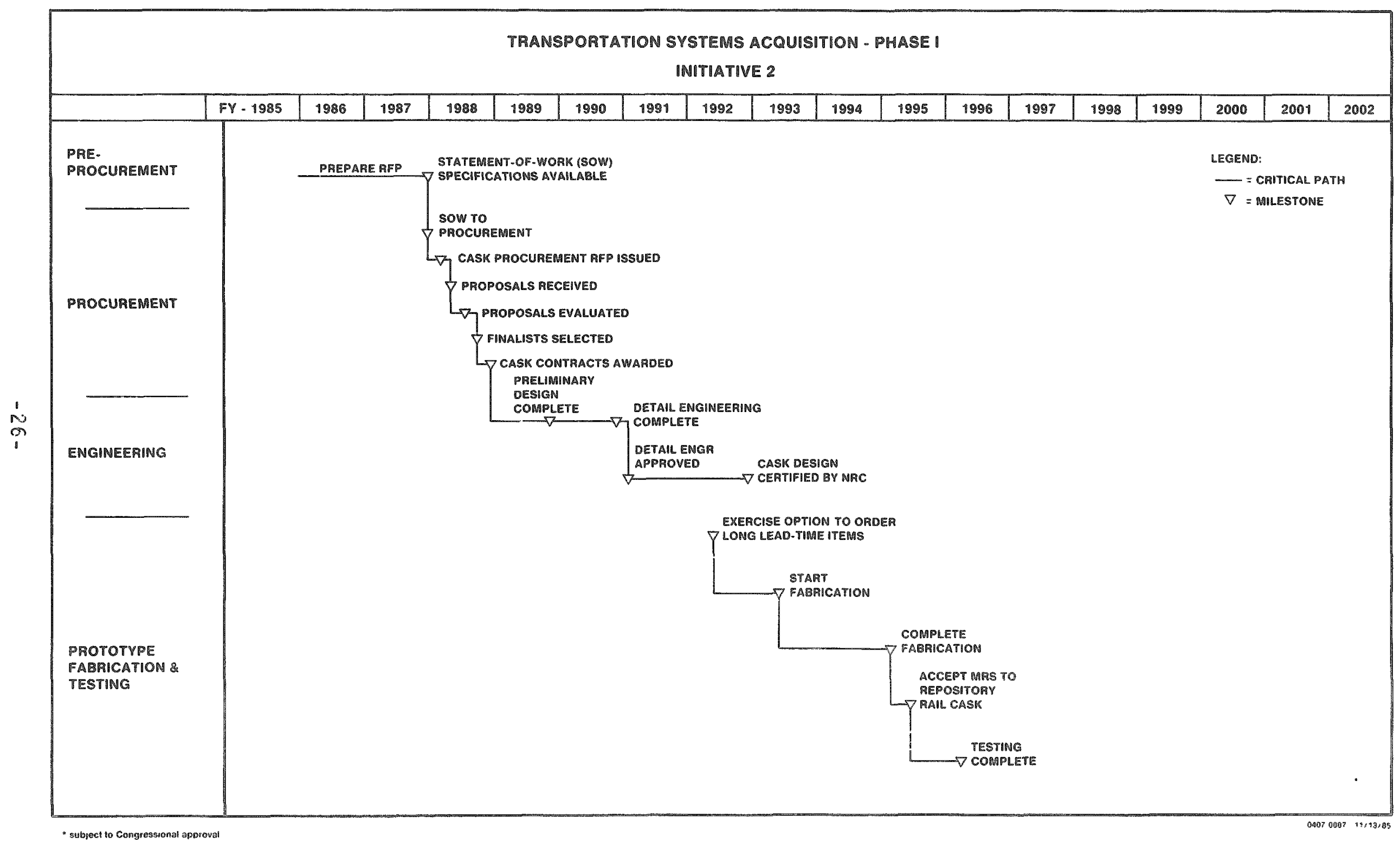

Figure 4-2. From-MRS*-to repository cask development schedule. 


\subsection{Initiative 3 - Nonstandard Spent Fuel and Components Casks}

The DOE Will procure casks as needed for the transport of special materials such as nonstandard spent fuel and non-fuel materials that must be disposed of in a geologic repository.

\subsubsection{Business Strategy}

The third cask development initiative under Transportation Systems Acquisition Phase $I$ will be the procurement of casks for transporting nonstandard spent fuel and non-fuel materials destined for the Federal repository such as control spiders, burnable poison rod assemblies, control rod elements, thimble plugs, fission chambers, neutron sources, or other high-level waste as defined under the Act. If these materials cannot be efficiently transported in the casks leveloped under the aforementioned initiatives or in NRC-certified casks developed independently by private companies, the DOE will acquire at least two new specialty cask designs to accommodate such shipments.

If developing new casks for the nonstandard materials is more efficient and more cost-effective than existing or available casks, the DOE will pursue a cask development process that is similar to those of Initiatives 1 and 2. The request for proposals (RFP) for nonstandard spent fuel and components cask development is expected to be issued in the mid-1990s.

\subsubsection{Procurement/Technical Plan}

Initiative 3 of Phase $I$ is divided into five work elements: nonstandard spent fuel and components characterization, procurement, existing cask applications evaluation, cask development, and prototype cask fabrication and testing.

\section{Nonstandard Spent Fuel and Components Characterization}

Nonstandard spent fuel or non-fuel wastes that are not included in the approved contents of the DOE's regular cask fleet will be cataloged and characterized. Where possible, these special materials will be cataloged into similar categories.

\section{Procurement}

The casks to be used to transport special materials will be required to be competitively procured. Responding organizations may propose to use casks with existing valid NRC certificates of compliance; to amend the NRC certificates of casks developed under Initiative 1 or developed independently by the biddex; or to develop new casks for the special materials. Depending on the volume and character of the special materials, the DOE may use al1 or some of these three potential options. After selection of finalists, contracts will be negotiated and awarded. 


\section{Existing Cask Applications}

Nonstandard spent fuel and components casks with valid NRC certificates of compliance will be evaluated and referred to the service contractors for fleet procurement. For cases where cextain materials are not included in the existing certificate of compliance, the DOE will support the cask contractor in preparing for submission to the NRC any required safety analysis report for packaging (SARP) amendments. Upon obtaining a valid certificate, the cask will be referced to the service contractor for fleet procurement.

\section{Cask Development}

The DOE will support the development of new casks for nonstandard spent fuel and non-fuel materials if this development can be shown to be cost-effective. OCRM will follow the methods used in Initiatives 1 and 2 to procure prototype units.

\section{Prototype Cask Fabrication and Testing}

The DOE will have private industry fabricate, if necessary, one or more prototypes of each new cask that it expects to include in its fleet. Upon acceptance of a prototype, the cask will be subjected to a test and evaluation sequence, as necessary.

\subsubsection{Schedule}

The projected Nonstandard Spent Fuel and Components Cask schedule is shown in Figure 4-3. The following are major milestones in this schedule:

- Release special-materials catalog

- Issue Nonstandard Spent Fuel and Components Cask RFP

1993

1994

\subsection{OCRWM Program Management/Contro1 P1an}

\subsubsection{Technical Management Structure}

The prototype cask development tasks will be administered for the office of Storage and Transportation Systems (OSTS) through a Transportation System Acquisition Project office under the DOE Idaho Operations office (DOE/ID). The cask development contracts will be solicited, awarded, and managed by this Project office. State, Tribal, and local governments may provide input to cask development through the OSTS. Utilities and affected institutions may also provide input through the OSTS. To accomplish Phase I activities, the organization structure shown in Figure $4-4$ will be established. Through the DOE/ID Project Office, the Transportation and Waste Systems Division of the OSTS Will use EG\&G Idaho, Inc. as the program management/quality assurance support contractor to provide technical overview of the various cask development contractors. Sandia National Laboratories (SNL) will provide independent technical assistance and test evaluations and will address regulatory and technical issues that apply to the overall cask development program. 


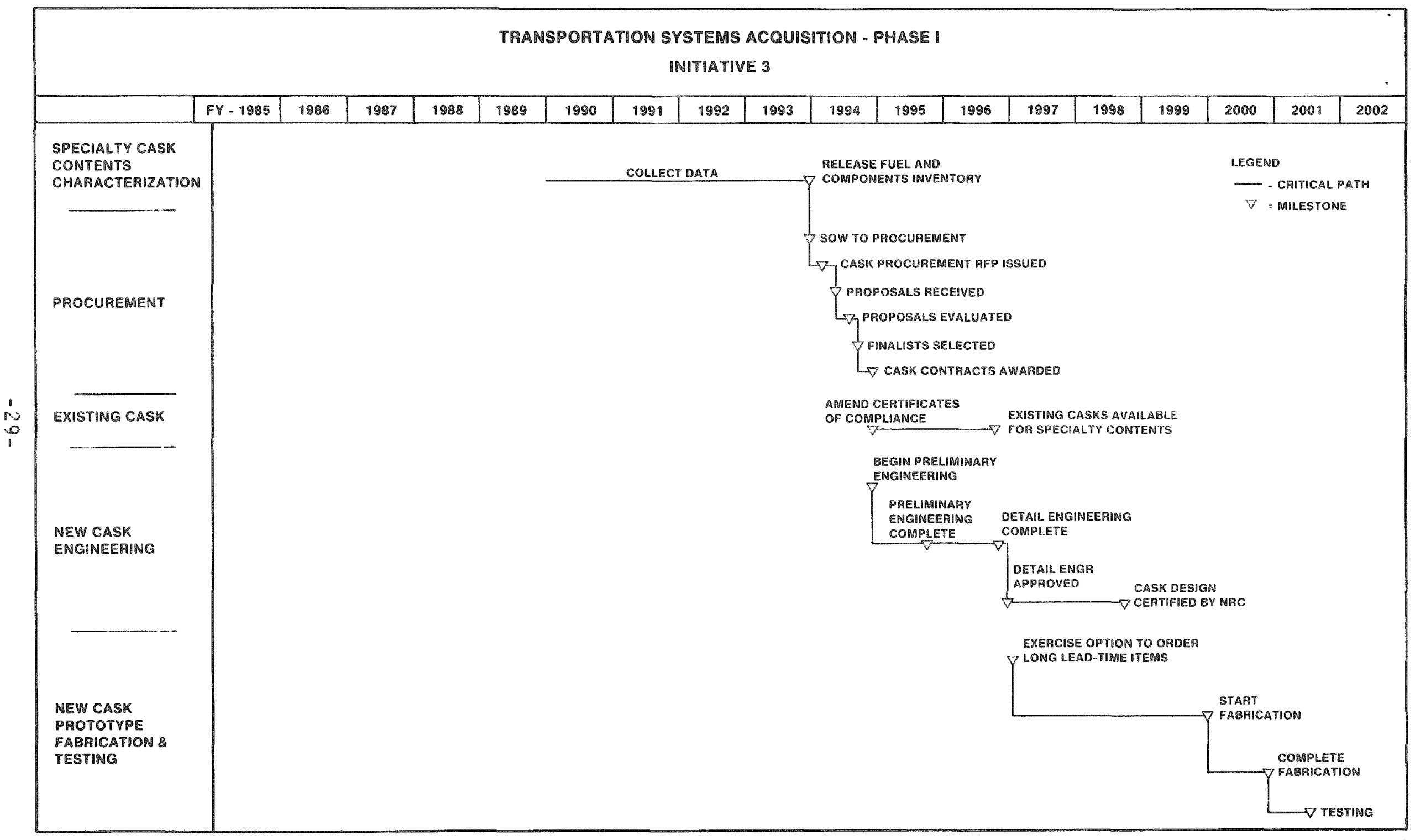

Figure 4-3. Nonstandard spent fuel and components cask development schedule. 


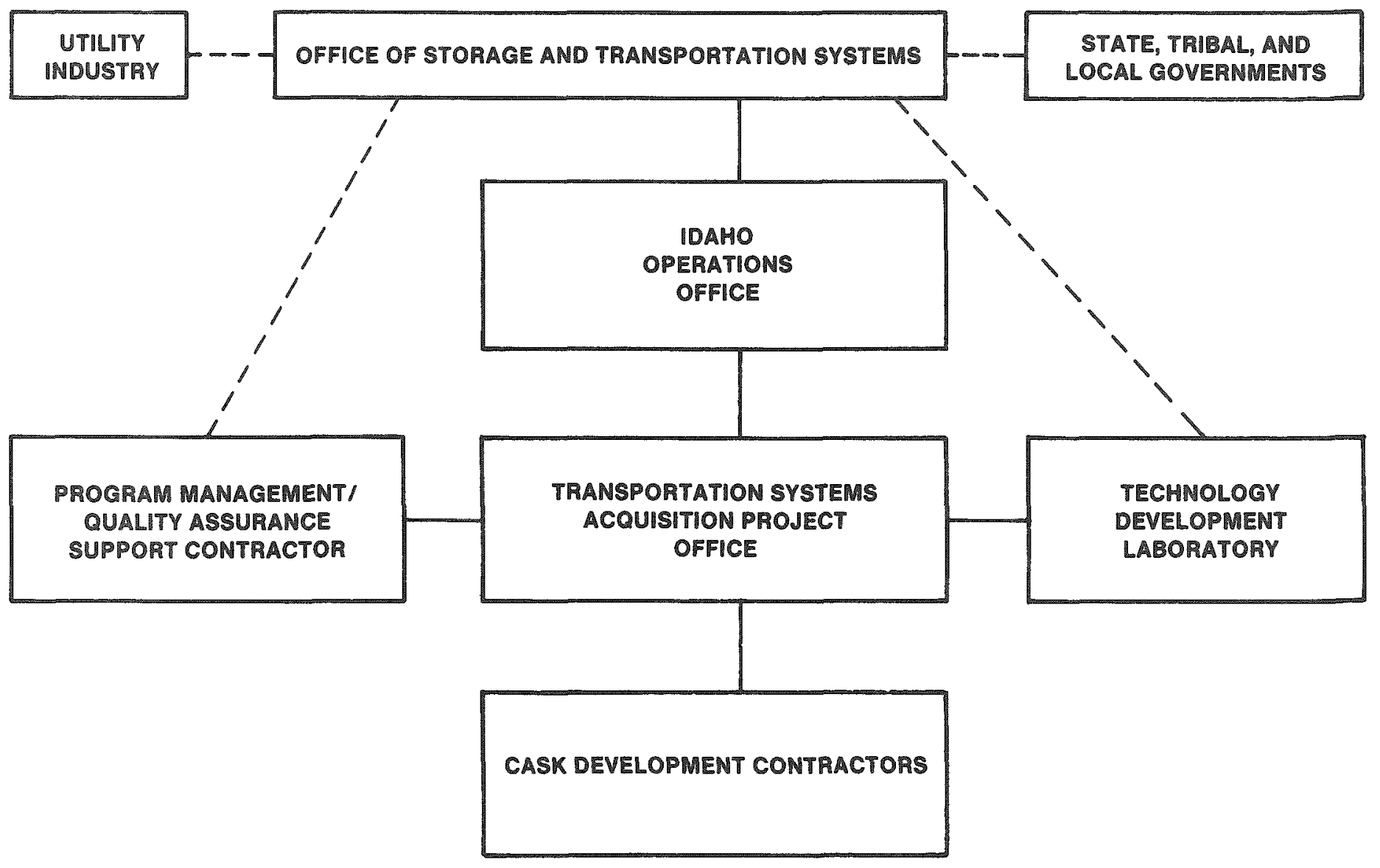

NOTES:

AUTHORITY

- - - COMMUNICATION

Figure 4-4. Cask development program management structure. 


\subsubsection{Procurement Guidance}

OCRW provides the following policy guidance related to the cask development contracts.

\section{Request for Proposals}

An RFP will be issued for each cask development initiative. Proposers may request financial support for the entire cask development process. Proposers who choose to perform cask engineering with their own resources can receive financial support for cask prototype fabrication and testing if their designs have been certified by NRC. All proposals related to a given cask initiative must be received by the DOE at the same time. However, the various modal options (truck, rail/barge, dual-purpose, etc.) will be evaluated separately. Since contracts will be negotiated individually with selected proposers, the starting dates of the contracts may vary, which may result in a phased development of cask designs.

\section{Contracting Arrangenent}

The DOF will use cost-reimbursement or no-cost contractual agreements with those firms that wish to retain design ownership during cask development. Cost-reimbursement contracts require that

1. The contractor's accounting system is adequate for determining costs applicable to the contract.

2. Appropriate Government supervision during performance will provide reasonable assurance that efficient methods and cost-effective controls are used.

\section{Alternative Contract Arrangements}

For contracts written to supply cask fabrication and testing on casks that have been developed at private expense, alternative contract provisions may be negotiated with respect to confidential or proprietary design information.

\section{Propriecary Items}

The DOE will protect proprietary information contained in proposals as set forth in the notice below. To protect such data the proposer should specifically identify each page, including each line or paragraph thereof containing the data to be protected, and mark the cover sheet of the proposal with the folloring notice: 
The data contained in pages of this proposal have been submitted in confidence and contain trade secrets or proprietary information, and such data shall be used or disclosed only for evaluation purposes, provided that if a contract is awarded to this proposer as a result of or in connection with the submission of this proposal, the Government shall have the right to use or disclose the data herein to the extent provided in the contract. This restriction does not limit the Government's rights to use or disclose data obtained without restriction from any source, including the proposer.

The DOE will acquire unlimited rights in any cask design developed or delivered under a DOE contract provided, however, that in contracts not including design and engineering, alternative provisions may be negotiated for the protection of privately developed confidential design or other information. Additionally, a contractor can protect its proprietary interest in any invention made prior to contracting by securing patents thereon. While the Federal Government may use items covered by privately owned patents for Governmental purposes, the patent owner may obtain compensation based on the DOE's use of privately owned patented inventions.

\section{Organizational Conf1ict of Interest}

The DOE may not award a contract to any firm that has an organizational conflict of interest (OCI). A firm with an OCI is defined as

1. Any organization that may be biased so as to affect the outcome of its work for the DOE.

2. Any organization that has a competitive advantage by virtue of any ongoing DOE contracts.

Prospective bidders will be furnished with complete information on oCI and the OCI disclosure requirements.

\section{F1eet Procurement Contract Plans}

Under Transportation Systems Acquisition Phase I, the DOE will establish a matrix of qualified NRC-certified cask designs. Prototype units that are procured under the cask development initiatives will be tested and results will be evaluated by the DOE to determine the acceptability and attributes of each design. The DOE will require the Phase II service contractor to procure a fleet of casks competitively. Cask selection will be based on units that provide the lowest life-cycle costs and other elements cxitical to the DOE.

\subsubsection{Contro11ed Items}

After each cask design initiative contract is awarded, the DOE will concentrate on monitoring certain system parameters during the cask development process. 


\section{System Performance Parameters}

The following major system performance parameters wi11 be monitored:

- Design safety relative to NRC and DOT performance standards.

- Payload.

- Turnaround time and compatibility with utility handling facilities.

- Cask size and weight limits.

- Gross vehicle size and weight limits.

- Operating-personnel radiation exposure.

- Contamination control measures.

\section{Cost Parameters}

The following major cost parameters will be monitored:

- Cask development cost per metric ton of payload.

- Estimated cask fabrication cost per metric ton of payload.

- Life-cycle cost estimates per metric ton of payload.

\section{Schedule Parameters}

The ability to fabricate casks in time to service the disposal system prior to 1998 will be monitored.

\subsection{Contingent Actions}

In the unlikely event that no private companies respond with acceptable proposals after the issuance or modified reassurance of an RFP, the DOE will use its existing contractors and national laboratories for cask development. 
THIS PAGE WAS

INTENTIONALLY

LEFT BLANK 
Chapter 5

\section{TRANSPORTATION SYSTEMS ACQUISITION PHASE II--SERVICE CONTRACTORS}

The DOE will develop a transportation system to conduct civilian waste shipments as required. This includes, but is not limited to, ensuring the availability of a sufficient quantity of casks for a transportation fleet, arranging carriage activities, servicing equipment, inspecting equipment and operations, interfacing with emergency-response organizations, and training of al1 operations personnel. The DOE will competitively place with private industry transportation operations service contracts. The selected contractors will be responsible for completing all technical and administrative tasks needed to ship waste from generators to Federal waste facilities. The inclusion of defense wastes in activities under this phase is currently being evaluated within the DOE. Where appropriate, the DOE wi11. provide technical assistance to the service contractors and will maintain independent auditing and technical supervision for inspection, quality assurance, or management purposes.

\subsection{Business Strategy}

In Transportation Systems Acquisition Phase II, the DOE will establish an operating transportation system using private industry to the maximum extent possible. First, the DOE will establish efficient and cost-effective service arrangements. As its first choice, the DOE expects to issue a request for proposals to private companies to act as service contractors for transportation operations. Upon placement of these contracts, the DOE plans to direct the service contractors to procure a transportation fleet from the Phase I matrix of qualified casks. Al1 civilian waste transportation operations will be subject to regulations of the NRC and the DOT. The transportation cask fleet will consist of a combination of modal designs that will most efficiently service the operating system. However, some cask diversity will be maintained to reduce the risk of adverse system impacts resulting from the unexpected loss of availability of any single design or procurement source.

\subsubsection{Service Contractors}

As directed by the Act, the DOE intends to use private industry to the maximum extent possible in each aspect of the transportation system. The DOE has an established history of successfully using contractors for the operation of many facilities conducting tasks critical to maintaining national security. The use of contractors does not diminish the DOE's responsibilities or commitment to safety but does allow for the effective assemblage of knowledgeable and skilled personnel to conduct specific operations. The Office of Civilian Radioactive Waste Management will develop and issue all service guidelines and specifications that will be implemented by its contractors. The DOE will also provide rigorous supervision of the quality assurance activities of its contractors. OCRWM is interested in pursuing the concept of service contractors to operate the fleet that will carry shipments of radioactive waste to disposal facilities. The service contracts will be competitively awarded to qualified bidders. 
Under these contracts, the service contractors will procure a fleet of qualified casks to carry spent fuel and high-level radioactive waste. Their tasks will also include making carrier arrangements, maintaining equipment, inspecting equipment and operations, and training a11 operating and security personnel.

To enhance accountability and to develop focal points of experience on its shipments, OCRWM may use regional service contractors to transport wastes from all of the reactors or facilities in a specified geographic area. This concept will be evaluated and compared to the benefits of using a single national comprehensive service contractor or numerous individual contractors. The use of a few regional service contractors is expected to be more effective than the use of numerous individual contractors. A regional approach can provide significant benefits of providing a backup capability should any single contractor experience difficulties. Additionally, the use of a regional system could result in more productive relationships between contractors and State, carrier, and utility officials.

\section{Cask Ownership}

Determining the appropriate modal mix and establishing the number of casks required are important in meeting complex operational needs. The DOE's goal is to ensure a sufficient supply of shipping casks at an acceptable total system life cycle cost to utility rate payers. From a comparative cost basis, the cask ownership decision will be substantially influenced by changing marketplace conditions. Examples of these conditions or factors are capital costs to both Federal and private organizations and changes in tas policy conditions such as depreciation allowances. Internally, OCRWM budgeting, purchasing, and waste fund investment policies will also affect the cost of cask ownership. In preliminary evaluations, OCRWM has identified scenarios where either Federal or private industry ownership is the most efficient option. Consequent1y, the DOE will defer a decision on cask ownership until the time period immediately preceding the fabrication of the cask fleet, $i, e$, in or near 1990. The decision by the DOE will be based on safety, cost, and quality assurance considerations.

\subsubsection{Carriage Arrangements}

The DOE will discuss transportation requirements with potential operators in order to coordinate near-term system needs until service contracts are evaluated and awarded. These activities will include, but are not 1 imited to, early discussions during the late 1980 s with truck and rail carriers that would potentially service the disposal systern.

If service contracts are awarded to private companies, these organizations would be required to conduct carriage arrangements subject to the DOE transportation policy that is in effect at the time shipments commence. The office of Civilian Radioactive Waste Management will provide program supervision in all carrier discussions and negotiations. Although details depend on the actual placement of contracts, the service contractors will be a focus of expertise in the transport of radioactive waste and will thus make appropriate shipping arrangements with common or contract carriers. Since the DOE will be the official shipper of radioactive waste, all transportation operations will be conducted under rigorous DOE supervision. 


\subsubsection{Training}

In developing its transportation program, the DOE assumes the major responsibility of establishing rigorous guidelines for personnel training related to waste shipments. The DOE will establish training guidelines consistent with NRC and DOT requirements that contribute to operational safety and that reinforce public confidence in the transportation system. Training comprises many elements including the instruction of drivers, maintenance and service mechanics, inspectors and security personnel and emergency-response organizations. Once guidelines are established, the DOE will ensure that training will be conducted by the service contractors in accordance with NRC and DOT requirements. Where appropriate and approved by the DOE, training may be conducted by separate private organizations. This is particularly true where independence is deemed necessary. The DOE will oversee training activities and update guidelines as required.

\subsubsection{Inspection, Maintenance, and Repair}

Inspection, maintenance, and repair of casks and associated transportation equipment will be an important part of future large-scale transportation operations. The DOE will develop rigid inspection criteria in coordination with the U.S. Department of Transportation (DOT) and periodic compliance testing procedures that the service contractors will be expected to adhere to and execute. The DOE will establish rigorous maintenance guidelines that are consistent with NRC and DOT requirements and will provide supervision to ensure that these guidelines are followed. Both scheduled and unscheduled maintenance capabilities for transportation equipment must be provided. It will be the responsibility of the service contractors to organize and implement the required inspection, maintenance, and repair capabilities and to rigorously enforce quality assurance standards established by the DOE. In addition, oCRWM will audit and independently verify the acceptability of inspection and quality assurance actions.

The DOE expects that the service contractors will be responsible for conducting required maintenance. Federal waste facilities will be able to perform routine in-service inspections, servicing, or minor repairs and will ensure that equipment can be safely shipped to a comprehensive facility. The DOE could also develop specialized comprehensive cask and vehicle maintenance facilities at its sites or provide land or space for this purpose if preferred by the service contractors. Utilities will be expected to perform routine in-service inspections and repairs and to ensure that casks can be safely shipped to a Federal facility.

\subsubsection{Service Contractor Interfaces with Utilities}

The service contractors will arrange for casks to be furnished to each utility in enough time to accommodate scheduled shipments. Such casks will be suitable for use at utility sites as determined during prior negotiations between the DOE and each utility. Under the contractual agreements with the DOE, the utilities will make all preparations to receive the shipping casks and will perform the required loading and inspection activities necessary for transportation. In general, utilities will assist the DOE and its contractors 
in completing tasks necessary for of site shipment to Federal facilities. Preparatory activities made by a utility will be in accordance with a11 applicable laws and regulations. The DoE may designate its personnel or those of its service contractors to observe the shipment preparations conducted at the utility site. Onsite acceptance by the DOE representative will be required prior to shipment. Each utility will afford access to such personne1. Each utility will perform any routine inspections or servicing and will provide protection and preservation of the casks furnished to it.

\subsection{Procurement/Technical Plan}

Transportation Systems Acquisition Phase II is divided into six work elements: early carrier negotiations, preprocurement planning, service contractor procurement, fleet procurement, preoperational preparations, and transport operations. Actions within each of these work elements are reviewed in the following sections.

\subsubsection{Early Carrier Discussions}

The DOE will discuss with operators during repository and storage facility siting evaluations the carrier rates and the terms and conditions of transport. The results of these early discussions will provide input to the DOE's final modal strategy (truck, rail, and barge) and assist in evaluating options to upgrade cask handing capabilities at selected waste generator sites.

\subsubsection{Preprocurement Planning}

The detailed responsibilities of service contractors will be established. An evaluation of the use of a single national service contractor, regional service contractors, and conventional carriage and service options will be made. Overview and audit tasks that should be performed by organizations independent of the service contractors will be defined. Al1 tasks needed to issue a service contractor RFP will be completed.

\subsubsection{Service Contractor Procurement}

The service contractor RFP will be issued by the Transportation Operations Project office to all organizations responding to the Commerce Business Daily and Federal Register announcements. Responding proposals will be evaluated against rigorous performance standards.

\subsubsection{Fleet Procurement}

The prototype casks from Transportation System Acquisition Phase I wi11 be supplied to the service contractors for nondestructive preoperational evaluations and testing. The DOE will establish a matrix of casks based on the preoperational evaluations, knowledge of the handing capabilities of the waste generators to be served, and information on modal costs and

preferences. OCRMM supervision will include the implementation of a rigorous 
quality assurance program during fabrication. The DOE will have independent supervision of this activity to ensure that all quality assurance requirements are met.

\subsubsection{Preoperational Preparations}

Prior to transportation operations, many actions must be performed by the service contractors. These include, but are not 1 imited to, making carrier arrangenents: establishing maintenance, repair, and inspection capabilities; developing training methods and materials: writing detailed operational procedures and manuals; training personnel; implementing a management and control system: interfacing with emergency-response personne1; and improving emergency-response capabilities. These actions will be completed according to the DOE's guidelines and will be subject to DOE overview.

\subsubsection{Transportation Operations}

Based on its contracts with utilities, the DOE will define waste pickup schedules on a continuous basis. The service contractors will then be responsible for completing all civilian waste shipments. This includes interfacing with utilities, States, and Indian Tribes to complete detailed transportation arrangements. All transportation operations wil1 be conducted in compliance with NRC, DOT, and applicable State regulations. OCRWM wi11 support or directly perform independent overviews of the service contractors" operations as deened necessary.

\subsection{OCRMM Program Management/Contro1 Plan}

\subsubsection{Techical Management Structure}

The Office of Storage and Transportation Systems (OSTS) will control spent fuel and radioactive waste shipments through a Transportation Operations Project office at the DOE Dak Ridge Operations office (DOE/OR). Service contractor contracts will be solicited, awarded, and managed by this Project Office under the direction of OSTS. To accomplish the DOE's transportation operational responsibilities, the organization structure shown in Figure 5-1 will be established. The OSTS will establish policy guidelines and will direct and supervise shipments through the Operations Project office. The service contractors will be responsible for the majority of transportation operation tasks. For activities where independent inspections or evaluations are prudent, the Transportation Operations Project office may fund separate contractors to perform activities as required.

\subsubsection{Procurement Guidance}

OCRM provides the following policy guidance related to procuring service contractors.

\section{Contracting Arrangement}

The DOE will competitively enter into service contracts with contractors. The DOE will select the cask ownership option that i.s most cost-effective at the time of fleet procurement. 


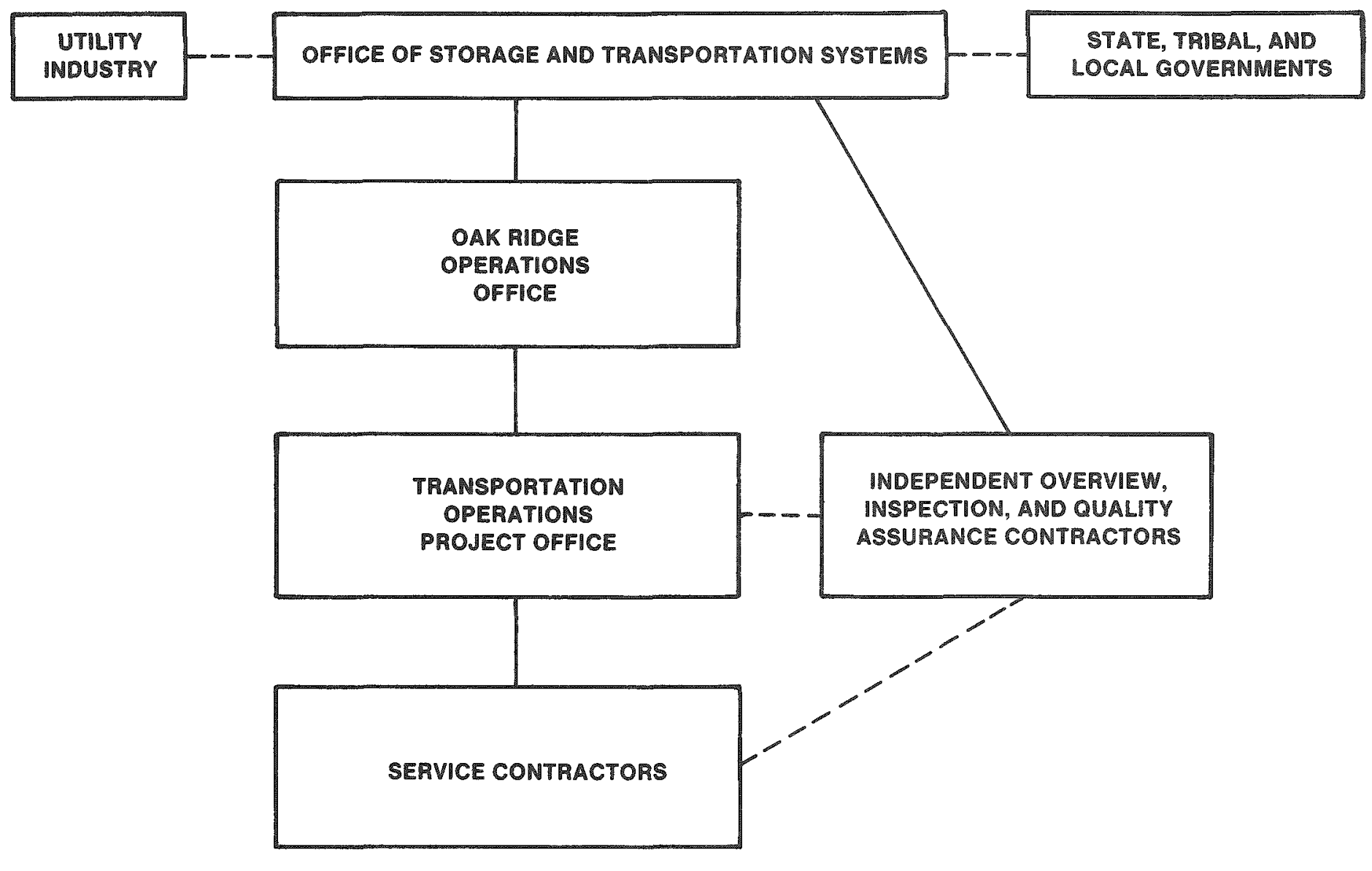

NOTES:

AUTHORITY COMMUNICATION

Figure 5-1. Transportation operations program management structure. 


\section{Terms and Conditions}

The DOE will use contract terms and conditions that are consistent with its standard procurement practices. Public liability protection that is equivalent to that afforded by the Government to the DOE's current facility and site contractors will apply.

\section{Contract Duration}

Contracts either will be of a 5-year duration or, because of the nature of the work, will be for the length of the tasks required under a management and operating contract. A decision regarding the type of contract to be awarded will be made at some future date.

\section{3 .3 Controlled Items}

The DOE will monitor certain system parameters during transportation operations.

\section{System Performance Parameters}

The following major system performance parameters will be monitored:

- Quality assurance parameters.

- Accident/incident rate.

- Cask acquisition process.

- Shipment miles per metric ton of payload transported.

- Average transport speed for each mode.

- Cask availability factor.

- Transportation equipment availability.

- Cask utilization factor.

- Transportation equipment utilization.

- Worker radiation exposure per metric ton of payload transported.

- Training hours per worker.

- Maintenance procedures for casks and other transportation equipment.

- Compatibility with utility handling facilities.

\section{Cost Parameters}

The following major cost parameters will be monitored:

- Transport cost per metric ton of payload per mile.

- Repair and maintenance cost per cask.

\section{Schedule Parameters}

The following major schedule parameters will be monitored:

- Metric tons of payload delivered per year.

- Percentage of on-time pickups and deliveries.

- Training schedule.

- Inspection schedule. 


\subsection{Schedule}

The Transportation System Acquisition Phase II schedule is shown in Figure 5-2. The following are major milestones in this schedule:

$\begin{array}{lll}\text { - Issue service contractor RFP } & 1990 \\ \text { - Award service contracts } & 1991 \\ \text { - First fleet cask operational } & 1995 \\ \text { - Initiate transportation operations } & 1996 \text { or later }\end{array}$

\subsection{Contingent Actions}

The DOE will establish procedures with the DOT, in accordance with Section 137 of the Act, to determine whether private industry is willing or able to provide transportation services at reasonable cost. In the unlikely event that no private companies respond with acceptable proposals to the service contractor RFP or if carriers are unwilling to transport this material, the DOE will consult with the Secretary of the DOT according to preestablished procedures. Should the Secretary of the DOT in consultation with the secretary of the DOE, determine that private industry is unable or unwilling to provide transportation services at reasonable cost, the DOE will use direct Federal services. 


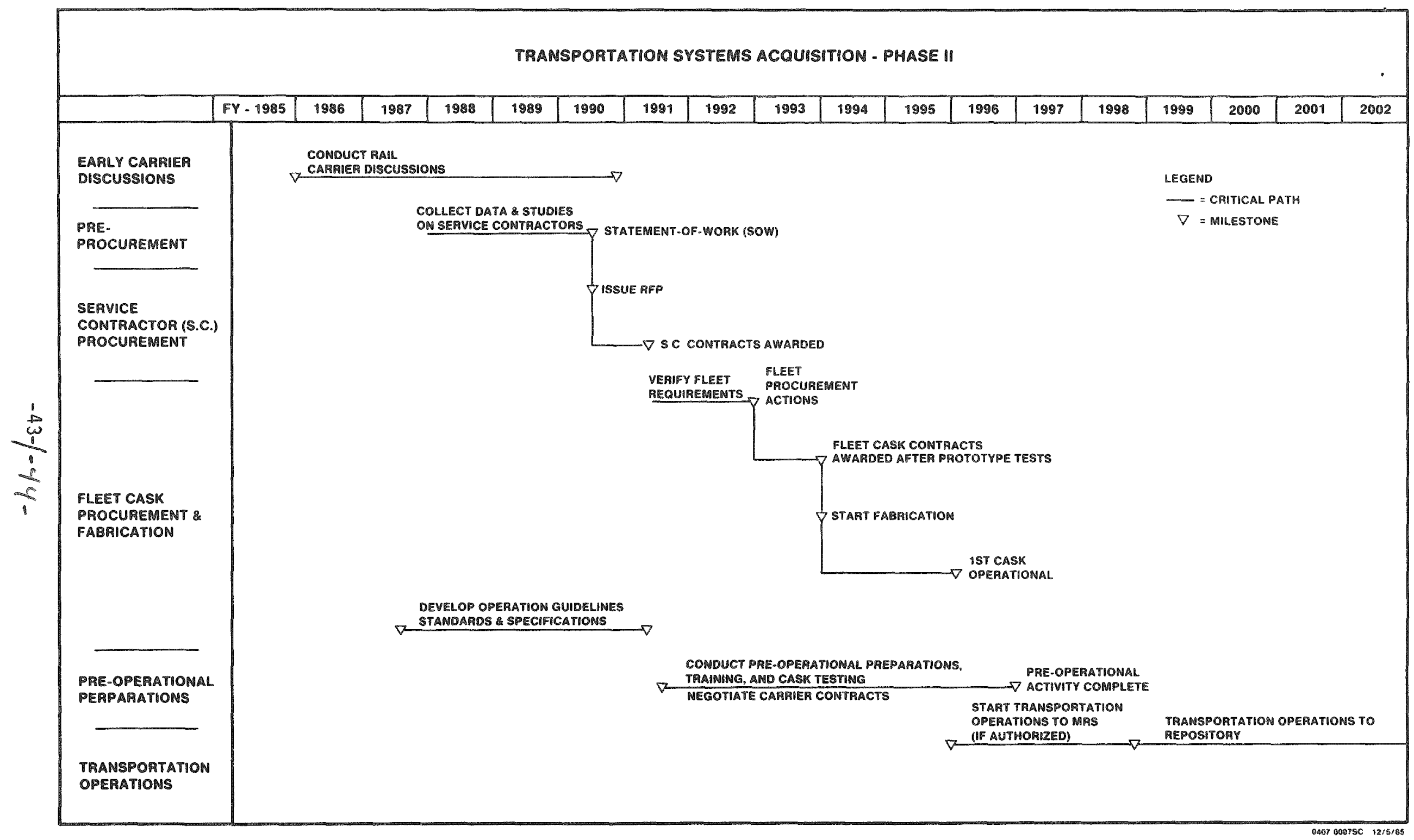

Figure 5-2. Service contractor 
THIS PAGE WAS

INTENTIONALLY

LEFT BLANK 
Chapter 6

\section{TRANSPORTATION INSTITUTIONAL PROGRAM ELEMENTS}

The Transportation Business Plan describes the Do:'s business approach to developing and eventually operating a transportation system. In attaining the goal of a safe, economical system that complies with the applicable legal and regulatory requirements, the DOE will consider the use of a wide variety of institutional factors. Such factors are made particularly important by the provisions for extensive public involvement contained in the Act and the impact of transportation on the waste program. Institutional factors are intricately intermeshed with nearly all aspects of radioactive waste management.

These institutional considerations, in turn, affect the business decisions of those who would supply transportation equipment and services to the DOE and of the utility rate payers who will pay for the transportation program through the Nuclear Waste Fund. Unresolved institutional issues create business risk as surely as technical issues. The DOE will seek to resolve institutional issues as it implements its mandate under the Act in fulfilling its objective of maintaining and enhancing the institutional relationships needed to conduct transportation operations in a publicly acceptable manner. The Doe includes a discussion of individual institutional issues in a separate plan that provides a framework for addressing such issues.

\subsection{Transportation Institutional Plan}

The Transportation Institutiona1 P1an (DOE/RW-0031, September 1985) defines DOE/OCRWM's relationships and interactions with external groups. Using this plan, the DOE seeks to resolve institutional issues by fully sharing information, carefully assessing the views of all concerned, and resolving differences.

Thus, the Transportation Institutional Plan provides the mechanism for identifying, analyzing, and resolving transportation issues. The plan also addresses development of outreach activities and materials. It should be emphasized that the issues and their resolution will not be part of the plan itself. Discussions of specific issues will be presented in a separate and evolving document entitled the Transportation Issues Discussion Document.

Many institutional issues in transportation could affect the way the DOE and its contractors execute program operations. Most of those issues listed above will affect either cask design, cask handling, or overall fleet operations. Resolutions of these issues will become part of the DOE's operating policies. Therefore, the Dor intends to commicate with business, utilities, governments, and other interested individuals and organizations on a continuing basis.

\subsection{Schedule}

The Transportation Institutional plan was published in draft form during the Fal1 of 1985. A final version is expected in the Spring of 1986, with periodic revisions 1ikely in the future. The DOE wil1 resolve individual issues as appropriate. Those issues affecting operations will be resolved before the anticipated 1996 date for beginning operations.

$$
-45-1 ; t
$$


THIS PAGE WAS INTENTIONALLY LEFT BLANK 
Appendix A

\section{WASTE ACCEPTANCE SCHEDULES\%}

The projected waste acceptance schedule for the authorized plan is shown in Table A-1. The schedule for the improved-performance plan is shown in Table A-2.

:Source: Mission Plan for the Civilian Radioactive Waste Management Program, DOE/RW-0005, Vo1. I, Part I, U.S. Department of Energy, Office of Civilian Radioactive Waste Management, June 1985.

$$
-47-10
$$


THIS PAGE WAS

INTENTIONALLY

LEFT BLANK 
Table A-1. Waste Acceptance Schedule-Authorized System (Metric tons of uranium (MTU) per year)

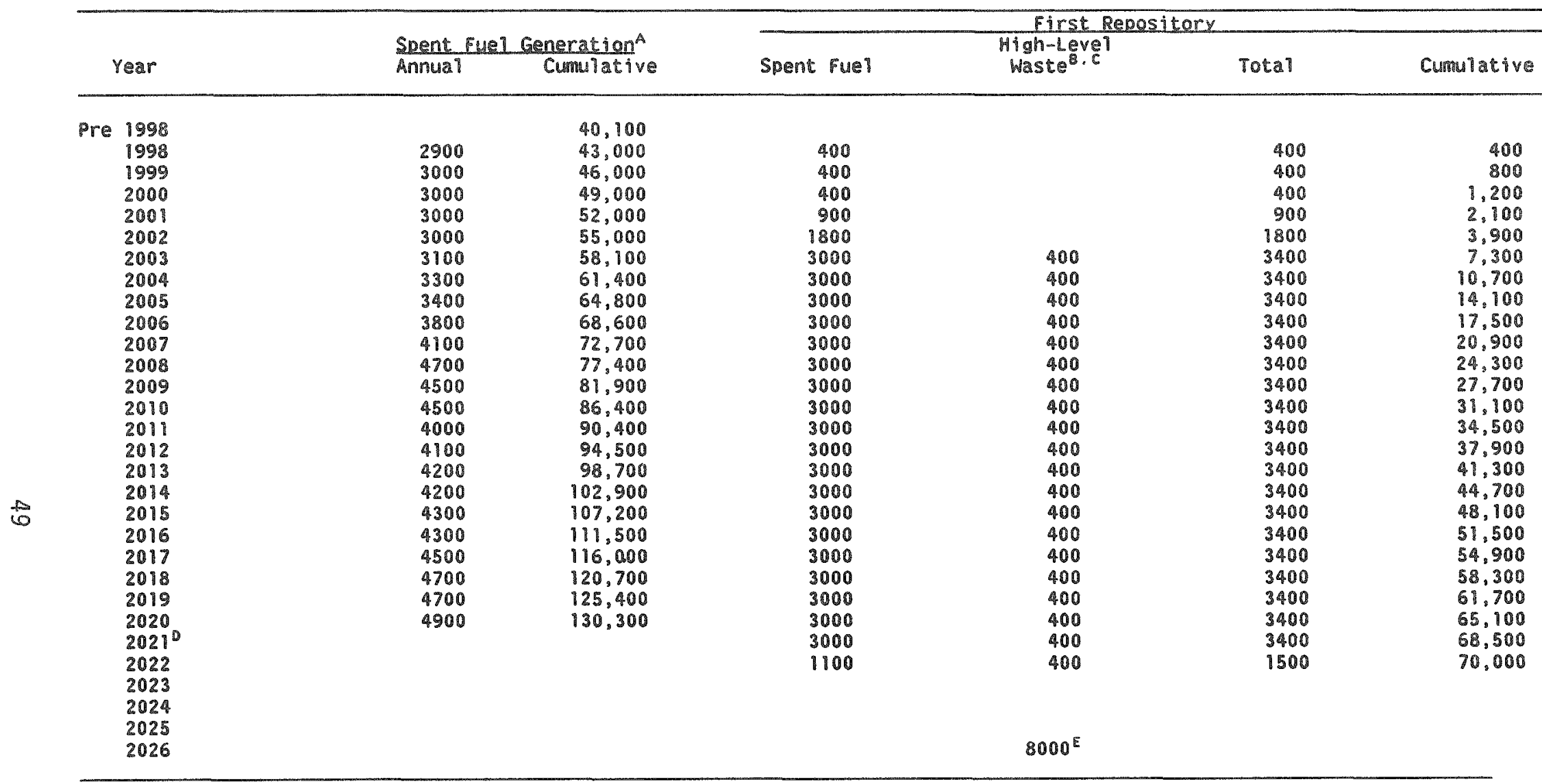

AData from Commercial Nuclear Power 1984: Prospects for the United States and the World, DoE/EIA 0438(84), November 1984. Includes discharge from decomissioned reactors.

B Approximate waste-acceptance rates for high-level waste from atomic energy defense activities and commercial high-level waste from the West valiey Demonstration Project. Quantities have been "nomalized" to metric tons of uranium (MTUs) on a curie-equivalent basis. Direct comparison with spent fuel is not equivalent, because defense high-level waste (oHLW) and commercial high-level waste (CMLW) resulted from the reprocessing of spent fuel. In the example, 400 MTU of defense waste equals 800 canisters. Actual acceptance rates are to be negotiated between Defense Programs and the office of civilian Radioactive Waste Management in the DoE.

The first repository currently is designed to begin operation in two phases. This example shows the acceptance of oulw and CMLW in the first phase when the second phase reaches its maximum receipt rate.

DTe Energy Information Administration projects spent-fuel generation only through the year 2020 . For waste created after 2020 , either the capacity of the first two repositories could be increased or additional repositories could be built.

The example shows a total of 8000 MTU of DHLW and CHLW emplaced by the year 2022. Additional oHLW can be accommodated by extending the operation of the first repository, emplacing ohLW in the second repository, or constructing additional repositories, as indicated in footnote $D$. 
Table A-2. Waste Acceptance Schedule--Improved-Performance System

(Metric tons of uranium (MTU) per year)

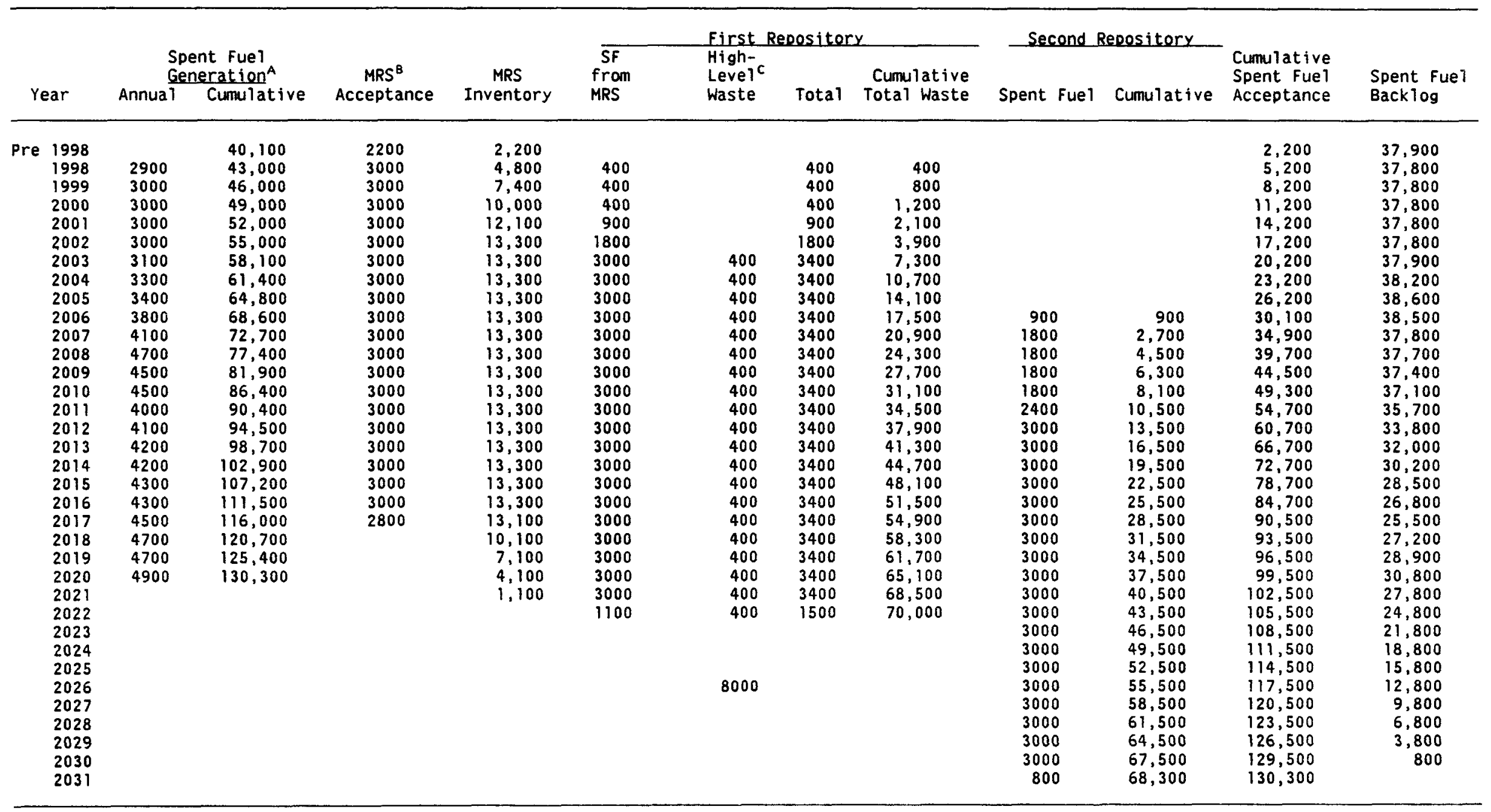

AData from Commercial Nuclear Power 1984: Prospects for the United States and the Wor1d, DOE/EIA 0438(84), November 1984. Includes discharga from decommissioned reactors.

MRs facility is assumed to reach a constant acceptance rate and discharge to the first repository as fast as the first repository can accept spent fuel. The MRS facility will stop accepting spent fuel when its inventory will fill the first repository.

See footnotes $b$ and $c$ in Table $A-1$. 
Appendix B

ILLUSTRATION OF THE IMPROVED-PERFORMANCE SYSTEM CONCEPT*

*Subject to Congressional approval. 

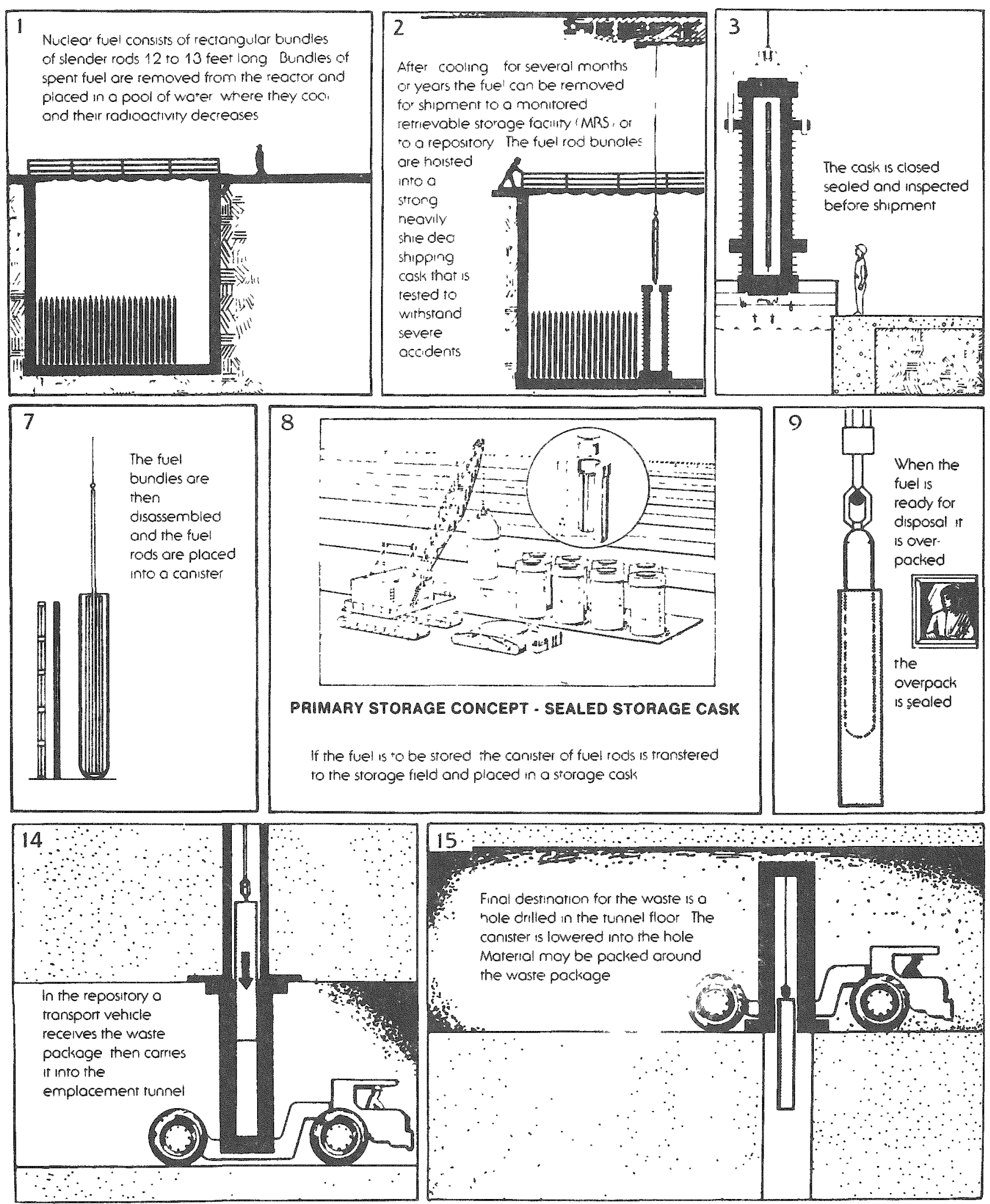

Illustration of the improved-performance system concept. 

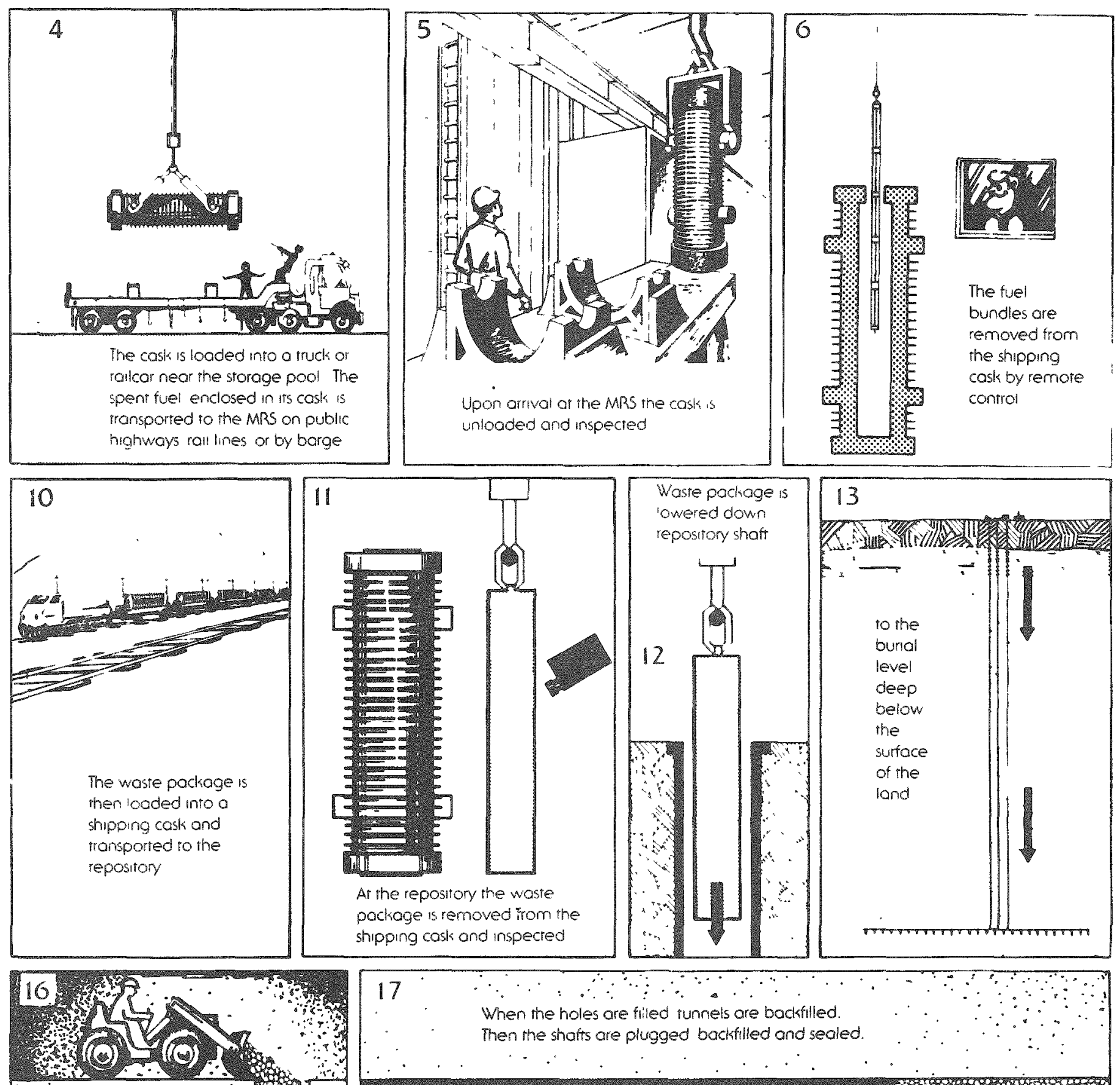

17

When the holes are filled tunnels are bockfilled.

Then the shatts are plugged backfilled and sealed.

A cop or plug is fitted into the hole and the hole is filled to the floor level with plugging mareial This provides rodiation shelding for workers
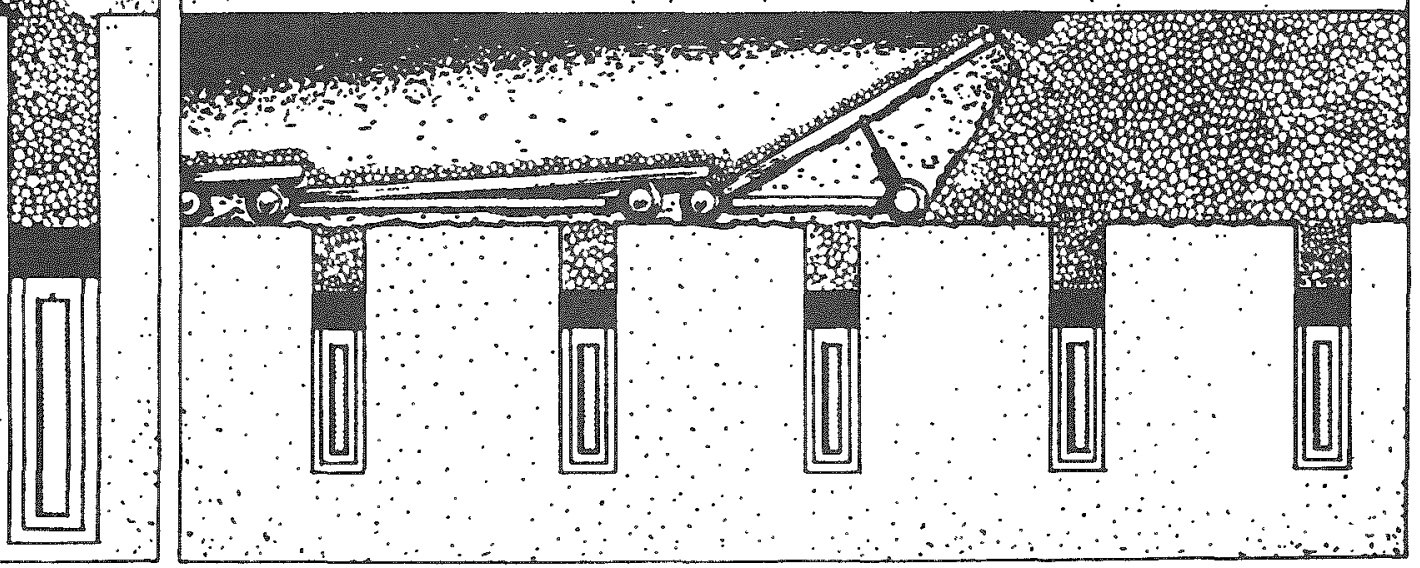

Illustration of the improved-performance system concept (continued). 